
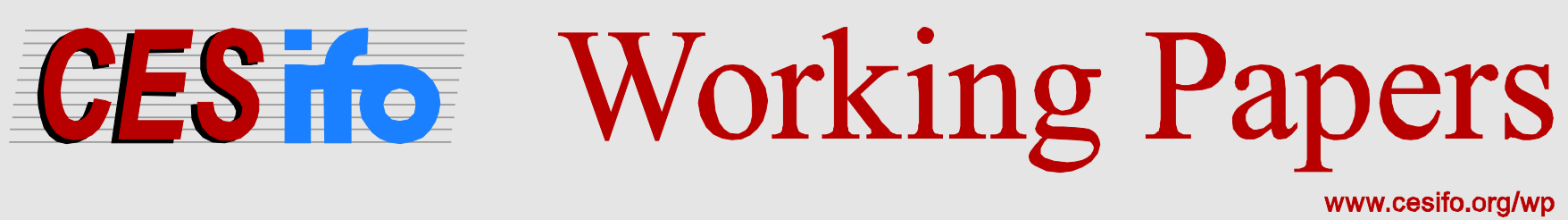

\title{
Opening Hours of Polling Stations and Voter Turnout: Evidence from a Natural Experiment
}

\author{
Niklas Potrafke \\ Felix Roesel
}

CESIFO WORKING PAPER NO. 6036

CAtegory 2: Public CHOICE

August 2016

An electronic version of the paper may be downloaded

- from the SSRN website:

- from the RePEc website:

- from the CESifo website:

www.SSRN.com

Www.RePEc.org

www.CESifo-group.org/wp 


\title{
Opening Hours of Polling Stations and Voter Turnout: Evidence from a Natural Experiment
}

\begin{abstract}
Voter turnout has declined in many industrialized countries, raising the question of whether electoral institutions increase voter turnout. We exploit an electoral reform in the Austrian state of Burgenland as a natural experiment to identify the causal effect of opening hours of polling stations on voter turnout. The results show that a 10 percent increase in opening hours increased voter turnout by some 0.5 to 0.9 percentage points. The effect is substantial because voter turnout was already around 80 percent before the reform in question. The results also show that the vote share of the conservative party decreased in the course of the reform, while the vote shares of the social democratic party and of the populist rightwing party (both parties attract blue-collar workers) increased. Enhancing participation in elections by extending the opening hours of polling stations remains a question to what extent politicians and voters believe that the benefits of higher voter turnout overcompensate for additional costs of longer opening hours.
\end{abstract}

JEL-Codes: D720, D020, Z180.

Keywords: voter turnout, party vote shares, opening hours of polling stations, natural experiment, Austria.

Niklas Potrafke*

Ifo Institute - Leibniz Institute for

Economic Research

at the University of Munich

Poschingerstrasse 5

Germany-81679 Munich

potrafke@ifo.de
Felix Roesel

Ifo Institute - Leibniz Institute for

Economic Research / Dresden Branch

Einsteinstrasse 3

Germany-01069 Dresden

roesel@ifo.de

*corresponding author

We thank Felix Arnold, Natalia Danzer, Andra Filote, Kai Gehring, Benny Geys, Arye Hillman, Andreas Peichl, Helmut Rainer, Sebastian Siegloch, Heinrich Ursprung, Yue Huang, the participants of the CGDE Doctoral Workshop (Magdeburg 2016), a seminar at the ifo Institute (Munich 2016), and the Silvaplana Workshop in Political Economy (Pontresina 2016) for helpful comments, and Lisa Giani-Contini for proof-reading. Kristin Fischer and Constanze Wobar provided excellent research assistance. 


\section{Introduction}

Voter turnout has declined in many industrialized countries. In the United States, for example, voter turnout in national elections decreased from 90 percent in 1968 to 43 percent in 2014. In Germany and Austria, voter turnout in national elections decreased from over 90 percent in the 1970s to around 70 percent in 2013. A pertinent question is therefore whether electoral institutions increase voter turnout. One approach is compulsory voting (Jaitman 2013, Fowler 2013, Ferwerda 2014, Lopez De Leon and Rizzi 2014, Bechtel et al. 2015 and 2016, Hoffman et al. 2016). Easy voter registration procedures, pre-registration laws, day-of-polling registration and postal voting have also been shown to increase voter turnout (Highton 1997, Besley and Case 2003, Burden et al. 2014, Luechinger et al. 2007, Hodler et al. 2015, Holbein and Hillygus 2016).

Another important electoral factor is the opening hours of polling stations. Yet there have been no studies identifying the causal effect of (extending) opening hours on voter turnout. Voter turnout may well be higher when voters have better opportunities and more time to go to the ballot box. 23 percent of all non-voters in Canadian federal elections in 2011, for example, described that they were "too busy" to vote, which was the most frequent answer beside "no interest” (28 percent) (Statistics Canada 2011). In the United States, Germany, Austria, and Ireland, for instance, extending the opening hours of polling stations is discussed in the public discourse. ${ }^{2}$ Descriptive evidence portraying correlations between the opening hours of polling stations and voter turnout for national elections is, however, mixed. Figure 1 shows that the opening hours of polling stations and voter turnout in national elections for OECD countries were hardly correlated over the period 2002-2015 (the

2 US: The Times-Picayune, 29.05.2012, http://www.nola.com/politics/index.ssf/2012/05/post_469.html; Germany: EurActiv, 19.09.2014, http://www.euractiv.com/section/justice-home-affairs/news/spd-mulls-super market-voting-booths-to-boost-election-turnout/; Austria: VOL, 22.01.2015, http://www.vol.at/laengerewahlzeit-soll-beteiligung-heben/vol-news-traffl-20041111-093017; Ireland: Houses of the Oireachtas, 04.07.2014, http://oireachtasdebates.oireachtas.ie/debates\%20authoring/debateswebpack.nsf/takes/dail2014070 400021?opendocument. 
correlation coefficient is $r=-0.04)$. Excluding the outliers Italy (IT) and Switzerland (CH) gives rise to a somewhat negative correlation (the correlation coefficient is $r=-0.36$ ).

[Figure 1 about here]

A negative correlation of voter turnout and opening hours would undermine the concept of increasing voter turnout by extending the opening hours of polling stations. In 2002, the Republic of Ireland had the lowest voter turnout in history (62.7 percent), despite the fact that the opening hours of polling stations were extended. Using data on the opening hours of polling stations and voter turnout in general elections across industrialized countries, however, is not suitable for deriving causal effects. Regressions of voter turnout on opening hours are very likely to be prone to reverse causality: when voter turnout is low, politicians are keen to extend opening hours to increase voter turnout. For example, the studies of Wolfinger and Rosenstone (1980) and Dropp (2012) may thus indicate a positive correlation between opening hours and voter turnout in the United States, but must be seen against the background of endogeneity and self-selection issues (we discuss more details in section 2.2).

We exploit a natural experiment in the Austrian state of Burgenland to identify the causal effect of opening hours on voter turnout. Traditionally, the opening hours of polling stations differ substantially across Austrian municipalities - even in national and state elections. Local opening hours depend on local preferences and customs. In 2015, an election reform gave rise to exogenous variation in opening hours. The reform compelled municipalities to extend their opening hours by an absolute amount of at least two hours at a second election day. Opening hours on the regular election day, however, did not change to a large extent. Voting opportunities thus changed differently in relative terms with respect to municipal pre-reform differences in opening hours. Following, for example, Finkelstein (2007), we exploit municipal differences in treatment intensity within a difference-indifferences model. Our results show that when opening hours were extended by 10 percent 
percent, voter turnout increased by around 0.5 to 0.9 percentage points, which is substantial because voter turnout was already around 80 percent before the reform. We show that other channels such as voting on the second election day are unlikely to drive our results.

We also examine to what extent longer opening hours influence the vote shares of individual parties. Previous studies have shown that leftwing parties benefit from electoral institutions that are intended to increase voter turnout (Fowler 2013, Ferwerda 2014, Fujiwara 2015, Bechtel and Schmid 2016, Hoffman et al. 2016). We corroborate these findings and show that the vote share of the conservative party (ÖVP) decreased significantly when opening hours were extended, while the vote shares of the social democratic party and the populist rightwing party (both parties attract blue-collar workers) increased.

\section{Related studies}

\subsection{Determinants of voter turnout}

Because voting is costly and individual votes are usually not pivotal, rational voters are predicted not to vote (Downs 1957). Yet people still vote (the voting paradox). A reason for voting is civic duty (Downs 1957, Riker and Ordeshook 1968). The question then remains who to vote for, given recognition that an individual vote is non-decisive. Expressive voting has been proposed to explain why people vote and who they vote for (Brennan and Hamlin 2000, Hamlin and Jennings 2011, Brennan and Brooks 2013). Hillman (2010) emphasizes the expressive utility from confirming identity and proposes that high-income voters are more likely to benefit expressively from voting. High-income citizens may also be more inclined to vote because they are better informed and better educated than low-income citizens (Frey 1971, Glaeser et al. 2006, Kasara and Suryanarayan 2015). More skilled citizens participate 
more frequently in elections than their unskilled counterparts (e.g., Tingsten 1937, Lijphart 1997, Dee 2004, Milligan et al. 2004).

Information about early voting is likely to influence voting behavior. Learning about the expected outcome of an election, through exit polls for example, will influence the behavior of individual voters. When voters know that a political party will win an election with certainty and voting is costly, rational voters may abstain from going to the ballot box because they know that their vote will not be pivotal. By contrast, when voters know that an election is close, they may well participate believing that they influence the outcome. Another issue is when voters receive utility from the act of voting either for the winner or the underdog. Exit poll information is then likely to give rise to bandwagon or underdog voting. ${ }^{3}$ In any event, exit poll information usually includes some uncertainty. An ideal empirical test on how information about early voting influences the voting behavior of later voters therefore requires knowledge of the early voting results. ${ }^{4}$ Morton et al. (2015) elaborate on the 2005 voting reform in France. The results show that knowledge of the election results on the French mainland decreased voter turnout in the French western overseas territories by about 11 percentage points.

Many other studies examine determinants of voter turnout. Geys (2006) and Cancela and Geys (2016) review studies that use voter turnout at the aggregate level (district, municipality, country) as a dependent variable. Geys (2006) concludes that population size and electoral closeness are significant explanatory variables: "Turnout is higher when the population is smaller and the election closer" (p. 653); and: "the institutional procedures governing the course of the elections strongly affect turnout. Compulsory voting, easier registration procedures, concurrent elections and the use of proportional representation all

\footnotetext{
${ }^{3}$ On expressive voting and behavior see, for example, Hillman (2010).

${ }^{4}$ For a normative analysis on sequential and simultaneous voting, see Hummel and Knight (2015).
} 
significantly stimulate turnout” (p. 653). Institutions, however, are often endogenous. Few previous studies exploit exogenous variation in voting institutions to examine the causal effects of what predicts voter turnout.

\subsection{Electoral institutions and voter turnout}

One would expect compulsory voting to increase voter turnout. Jaitman (2013) estimates the causal effect of compulsory voting on voter turnout in the 2009 legislative elections in Argentina using a discontinuity in the obligation to vote at the age of 70 in a Regression Discontinuity (RD) design. The results show that compulsory voting increased voter turnout by around 18 percentage points. Lopez De Leon and Rizzi (2014) use a discontinuity in the obligation to vote at the age of 18 in the 2010 Brazilian Presidential Elections and find that compulsory voting increased voter turnout by around 15 to 27 percentage points. In the Swiss canton of Vaud, compulsory voting also had strong effects on voter turnout. Sanctioned compulsory voting was present over the period 1925-1948 in federal referenda. By using a synthetic control group design, Bechtel et al. (2015) compare voter turnout in both the treatment and the post-treatment period. The results show that introducing compulsory voting increased voter turnout in federal referenda by about 30 percentage points. The effect of compulsory voting is even larger when using a common fixed effects model (Bechtel et al. 2016). In Australia, compulsory voting was introduced over the period 1914-1941 and increased voter turnout by around 24 percentage points (Fowler 2013). In Austria, compulsory voting laws were changed several times in the nine states since 1949. Hoffman et al. (2016) use variation arising from changes in compulsory voting laws and show that compulsory voting increased voter turnout by about 10 percentage points, from around 80 percent to 90 percent. Using municipality data the results of Ferwerda (2014) show that repealing compulsory voting in 1992 decreased voter turnout by about 8.6 percentage points. 
Switzerland is an excellent laboratory for examining whether lower voting costs due to postal voting influences voter turnout. The 26 Swiss cantons introduced postal voting at different points in time. The first canton to introduce postal voting was Basel-Land in 1978. The last two cantons, Valais and Ticino, introduced postal voting in 2005. Using data for national elections over the period 1970-2005, the results of Luechinger et al. (2007) suggest that voter turnout increased by around 4.1 percentage points on average. Using data for the period 1990-2010, the results of Hodler et al. (2015) suggest that voter turnout increased by approximately 5 percentage points. By contrast, the results of Funk (2010) suggest that the effect of postal voting on voter turnout was rather small, especially in municipal elections. The author uses different sizes of communities to disentangle the social-pressure effects on voting. ${ }^{5}$ The smaller the community, the larger the social pressure and, hence, the voter turnout; because citizens chat about who is taking the civic duty to vote seriously and who is not. Postal voting renders the voting act invisible to other citizens. The results do indeed show that the effect of postal voting on voter turnout was around 50 percent smaller in small compared to large municipalities. Using micro-data for about 79,000 voters over the period 1981-2009, the results of Bechtel and Schmid (2016) show that postal voting increased voter turnout in referenda by about five percentage points on average. Effects differ across the socio-demographic characteristics of the voters. In particular, postal voting activated citizens who were generally less interested in politics, non-highly educated individuals, as well as high income earners.

There have been studies of how electoral laws such as easy registration and early voting influence voter turnout in the United States. Burden et al. (2014) employ survey data and panel data on voter turnout in the 2004 and 2008 presidential elections and show that election day registration certainly increased voter turnout. Besley and Case (2003) use state-

\footnotetext{
${ }^{5}$ On social pressure to vote, see also Knack (1992) and Gerber et al. (2008).
} 
level data to show that day-of-polling registration gave rise to higher voter turnout. Highton (1997) shows that easy registration procedures increased voter turnout. Pre-registration laws, which allow young citizens to register before being eligible to vote, increased voter turnout. Holbein and Hillygus (2016) use data of the Current Population Survey in the United States and data for the state of Florida. The results show that pre-registration laws increased voter turnout by around 13 percent in the cross-US-states study and by about 8 percentage points in Florida. In Brazil, introducing electronic voting increased voter turnout by about 12 percentage points (Fujiwara 2015).

Previous studies ignored the opening hours of polling stations as an explanatory variable for voter turnout (and party vote shares to be discussed in section 2.3); exceptions are Wolfinger and Rosenstone (1980) and Dropp (2012). The hypothesis to be investigated is clear: extending the opening hours of polling stations increases voting opportunities according to the heterogeneous time preferences of voters. 23 percent of all non-voters in Canadian federal elections 2011 stated that they were "too busy" to exercise their right to vote (Statistics Canada 2011). Longer opening hours may increase the probability of matching voters' preferences and thus reducing the costs of voting. Voters who hesitate to participate in elections in particular may take advantage of longer opening hours, which are, in turn, likely to increase voter turnout. Dropp (2012) uses data for voter turnout in Minnesota, Montana and Vermont. Jurisdictions with fewer than 500 (or 400) residents were allowed to delay opening hours on election day by three (or five) hours in Minnesota and Montana. By employing a RD design for jurisdictions just below and above the 500 (or 400) resident threshold, the author relates changes in the opening hours of polling stations to voter turnout. In Minnesota, reducing the opening hours did not predict voter turnout. In Montana, by contrast, reducing opening hours by three hours was associated with decreases in voter turnout by around 2 to 4 percentage points. Using panel data for Vermont, the results do not show that opening hours 
were associated with voter turnout. However, municipalities decide on their selection into treatment, which may explain why the results are mixed.

Wolfinger and Rosenstone (1980) investigate the determinants of individual voting behavior in the 1972 US presidential elections. The authors employ micro-data from the Census Bureau and estimate a probit model to explain whether an individual voted. The results show that: "[k]eeping the polls open for fourteen hours instead of twelve hours increases from 1 percent to 3 percent the probability that an individual will vote” (p. 71 et seq.). However, using micro-data does not help to exclude the reverse causality of turnout and the opening hours of polling stations.

\subsection{Electoral institutions and party votes shares}

The benefits of high voter turnout are the likelihood of a changed majority outcome. An important question is which voters participate more actively in elections and which parties benefit when voter turnout increases - in the course of reformed electoral institutions. Leftwing politicians seem to believe that leftwing party-shares are low when voter turnout is low and advocate longer opening hours. A case in point is the proposal of the general secretary of the German leftwing Social Democratic Party (SPD) in December 2014 to open polling stations for a week or some weeks instead of just one day. Conservative politicians rejected the proposal. Another issue is whether leftwing or rightwing parties benefit from high or low voter turnout. Rightwing voters are usually expected to be more disciplined and to have a stronger sense of civic duty than leftwing voters. In Germany, the vote share of the leftwing SPD was low when voter turnout was low (Arnold and Freier 2016). The empirical evidence on whether rightwing parties benefit from low voter turnout is mixed for other countries (e.g., Knack 1994, Gomez et al. 2007, Hansford and Gomez 2010, Artés 2014, Lind 2013). 
Some of the previous studies investigating whether reforms in electoral institutions influence voter turnout also focused on party vote shares. In the Swiss cantons, for example, postal voting activated proponents of leftwing and centrist parties (Bechtel and Schmid 2016). Compulsory voting in the Austrian states somewhat increased the vote shares of the leftwing parties: using data across the Austrian states, the results of Hoffman et al. (2016) hardly predict any effect of compulsory voting on party votes shares. Using Austrian municipality data and focusing on the constitutional change in 1992, the results of Ferwerda (2014) suggest that the leftwing Social Democratic Party (SPÖ) benefited from compulsory voting. In Australia, compulsory voting increased the vote share of the leftwing Labor party by about 9 percentage points (Fowler 2013). Leftwing parties in Brazil somewhat benefited from introducing electronic voting (Fujiwara 2015). Our hypothesis to be investigated empirically is that the longer opening hours of polling stations increase the vote share of leftwing parties.

\section{Empirical analysis}

We use a natural experiment in the Austrian state of Burgenland. We take advantage of an electoral reform that gave rise to exogenous variation in opening hours and allows us to estimate the causal effect of opening hours of polling stations on voter turnout and on party vote shares.

\subsection{Institutional background}

Burgenland is the smallest of the nine states of the Republic of Austria in terms of population (2015: about 290,000). The largest city is the capital Eisenstadt with about 13,700 inhabitants. Burgenland was part of Hungary until 1921. Many languages are spoken in the 171 Burgenland municipalities: German, Burgenland-Croatian, Croatian and Hungarian. The municipalities have between one to eight localities (328 localities in total). Municipalities 
with only one locality (65 percent) and municipalities with multiple localities (35 percent) hardly differ in terms of average population (1,641 and 1,772 inhabitants). Municipalities are grouped into seven districts. $^{6}$

In Austria, electoral institutions such as the voting procedure, day of the election or ballot count are regulated by national and state law. By contrast, local authorities design the number, location and opening times of polling stations. There is no minimum number of opening hours. Municipalities differ in the opening and closing times of polling stations depending on local traditions and geography. For example, in the 2015 state election, the municipality of Heugraben closed its polling station at 8.30 a.m. (opening: 6.30 a.m.) half an hour before voting in the neighboring locality Rohr even began (09.00 a.m. to 1.00 p.m.). By law, municipalities have to provide at least one polling station for each of their localities on the regular election day. There were 429 polling stations in the 2015 state election.

In late 2014, the Burgenland state parliament passed an electoral reform for state and local elections (but not for national and presidential elections). 89 percent of all Members of Parliament (MPs) voted in favor of the reform (the MPs of the social democratic SPÖ, the conservative Party ÖVP, and the Green Party), while only three MPs from the populist rightwing Freedom Party (FPÖ) and the homeland party “Liste Burgenland” opposed it. The reform was intended to further increase voter turnout, which traditionally is already quite high in Burgenland (about 80 percent on average between 2000 and 2016), but was even higher in the late 1960s (1968: 95 percent). The electoral reform implemented a mandatory second election day, nine days in advance of the regular election day. Regular voting takes place on Sundays, the second election day is Friday. The core issue of the reform was that at least one polling station per municipality has to be opened for at least two hours on the second election

\footnotetext{
${ }^{6}$ The capital city of Eisenstadt and the city of Rust are districts on their own. Both cities are located in the urban north of Burgenland.
} 
day and to cover the time period from 6 to 7 p.m. In the subsequent 2015 state election, about 85 percent of all municipalities only fulfilled the minimum requirement of the additional two hours. Opening hours on the regular election day remained fairly unchanged. Figure 2 shows that municipalities opened polling stations for roughly six hours on average before 2015. Only very few municipalities slightly changed their opening hours compared to the election in 2013. ${ }^{7}$ We thus assume regular opening hours to be constant throughout the entire pre-reform period. The electoral reform gave rise to a higher level of about eight opening hours on average in 2015. State law, however, only applies to state and local elections. Hence, the opening hours of polling stations were not extended and returned to their pre-reform level in the 2016 presidential election. ${ }^{8}$

[Figure 2 about here]

The absolute differences in opening hours between municipalities hardly changed in the course of the reform. By contrast, the relative change in opening hours differs substantially between municipalities. For example, a municipality with four pre-reform opening hours experienced a relative increase of 50 percent in opening hours given the minimum requirement of two additional opening hours. If the municipality opened eight hours prior to 2015 the increase was only 25 percent. We exploit this variation in treatment intensity arising from pre-reform differences in opening hours.

\subsection{Identification strategy}

We use a difference-in-differences approach and year and municipality fixed effects to identify the causal effect of opening hours on voter turnout. Our approach is related, for

\footnotetext{
${ }^{7}$ The within coefficient of variation amounts only 0.06 . The coefficient of variation is computed as the ratio of the within standard deviation of opening hours (0.36) and the mean of opening hours (5.69).

${ }^{8}$ Presidential elections are different than state and national parliamentary elections. We include here the 2016 presidential election to show that the opening hours of polling stations returned to their pre-reform level in the 2016 presidential election. Inferences of our empirical results do not change at all when we exclude the 2016 presidential election.
} 
example, to Card (1992) and Finkelstein (2007). ${ }^{9}$ Card (1992) shows to what extent employment changed when the federal minimum wage increased in the United States. The effects differed across states depending on how many workers initially earned less than the new federal minimum wage. Finkelstein (2007) identifies the effect of introducing Medicare in 1965 on hospital spending. Health insurance coverage of the elderly differed substantially between states before Medicare was introduced in the United States. After the health care reform of 1965, insurance coverage was fairly equal across states. We exploit exogenous variation based on pre-reform differences in the same manner. Against the background of the different traditions in opening hours of polling stations in Burgenland, increasing opening hours by the same absolute amount of two hours implies different treatment intensities in terms of relative changes. Year fixed effects capture aspects of the reform, which influence all municipalities to the same extent.

The key identifying assumptions are (i) sorting into treatment intensity was exogenous and (ii) all municipalities follow a common pre-reform trend, which would have continued in the absence of the opening hours extension. By law, the treatment influenced all municipalities. Municipalities could not adjust opening hours in elections prior to the treatment because the state parliament did not deal with the electoral reform before 2014. The last elections before the reform were in 2013 (national elections) and 2010 (state elections). Around 67 percent of all municipalities did not change the regular (Sunday) opening hours of polling stations between 2013 and 2015. Opening hours on the regular election day changed by more than one hour between 2013 and 2015 in only 5 percent of all municipalities. Average opening hours on the regular election day (Sunday) thus remained fairly unchanged (2010: 5.8 hours, 2013: 5.7 hours, 2015: 5.5 hours). Figure 3 shows that treatment intensity

\footnotetext{
${ }^{9}$ Acemoglu et al. (2004) also exploit differences in treatment intensity using a difference-in-differences estimation. The results show that increasing WWII mobilization rate of men in US states gave rise to higher female labor supply.
} 
(i.e., the relative change in opening hours) is not correlated with pre-treatment voter turnout. The correlation coefficient of the change in opening hours and pre-reform voter turnout (state election in 2010) is $r=0.09$ and does not turn out to be statistically significant (see Figure 3).

[Table 1 about here]

We also examine whether municipalities differ in observable characteristics among the treatment intensity. Pre-reform characteristics of the municipalities should not predict treatment intensity. Figure A.1 in the Appendix shows that pre-treatment characteristics (including party vote shares) are hardly correlated with treatment intensity. The correlation of the change in opening hours and rainfall on the state election day in 2010 is the largest correlation coefficient among all other variables $(r=-0.348)$. To be sure, it is unlikely that rainfall on an individual day predicts changes in opening hours. Altogether, neither prereform voter turnout, nor previous party vote shares, nor other observable characteristics predict treatment intensity.

We distinguish between a subsample (panel A) and the full sample of municipalities (panel B see Table 1). Panel A is a strictly defined sample. This panel (strict sample) includes the 83 municipalities that fulfill the minimum requirement of two additional opening hours only and do not change opening hours at the regular election day between the 2010 and the 2015 state election. This rules out any strategic adjustment such as extending opening hours by more than two hours at the second election day (because, for example, municipalities expected voter turnout to increase due to the reform) or decreasing opening hours at the regular election day. Panel B includes the full sample of all 171 municipalities. Voter turnout (80.5 percent and 80.2 percent on average) and descriptive statistics of the explanatory variables, however, hardly differ between the two panels (see Table 1).

[Figure 3 about here] 
The assumption of common pre-reform trends cannot be tested but seems to be met: Figure 4 shows mean voter turnout for state and national elections since 2000 by three subgroups and indicates that the pre-reform trends are common. The subgroups are defined by pre-treatment opening hours, i.e. opening hours in 2010, and basically reflect the lower, center and upper 33 percent quantile in terms of opening hours. The municipalities of the three quantiles follow a common trend and exhibit similar means up to the electoral reform. Prereform characteristics should thus not influence "selection" into treatment. In the reform election of 2015, the trends of the three groups differ. The group with the lowest level in prereform opening hours experienced an increase in voter turnout, the center group hardly experienced any changes, and the group with a high pre-reform level of opening hours experienced lower voter turnout. In other words, the higher the relative change in opening hours, the higher the change in voter turnout. Remarkably, group spreads in voter turnout vanished in the 2016 presidential election when opening hours of polling stations were not extended, providing further strong support for common trends.

[Figure 4 about here]

We portray changes in voter turnout and in the opening hours of polling stations between the last pre-reform and the reform state election. Large increases in opening hours from 2010 to 2015 were associated with higher voter turnout, especially in the Southern part of Burgenland (Figure 5).

[Figure 5 about here]

Altogether, descriptive statistics indicate that longer opening hours did increase voter turnout. 


\subsection{Data and regression design}

We use data for the last four Burgenland state elections (2000, 2005, 2010 and 2015), the last four national elections (2002, 2006, 2008 and 2013), and the presidential election (first round) in 2016 (for details see Table A.1 in the Appendix). Extended opening hours of polling stations only applied to the 2015 state election. Election data are obtained from the Burgenland state administration and the Austrian Federal Ministry of the Interior. District administrations provided data on the opening hours of polling stations upon request. We compile data on other explanatory variables from the Federal Statistical Office of Austria, which we will explain in more detail below.

Our difference-in-differences OLS model with fixed effects takes the following form: ${ }^{10}$

$$
\begin{gathered}
\text { Turnout }_{i t}=\alpha_{i}+\delta_{t}+\beta\left(\text { Treat }_{i} \times \text { Reform }_{t}\right)+X^{\prime}{ }_{i t} \gamma+\varepsilon_{i t} \\
\text { with } i=1, \ldots, 171 \text { and } t=1, \ldots, 9
\end{gathered}
$$

where Turnout $_{i t}$ describes the share of voters in municipality $i$ at election $t$. Treat describes the relative change in opening hours provided in municipality $i$. We compute Treat $_{i}$ as follows: Treat $_{i}=\left(A d d_{i, 2015} / \operatorname{Reg}_{i, 2015}\right) \times 100 . A d d_{i, 2015}$ describes opening hours at the additional election day in municipality $i$ in 2015 (in most cases: two hours) and $\operatorname{Re} g_{i, 2015}$ describes opening hours at the regular election day in 2015. $\operatorname{Reg}_{i}$, however, is hardly time-invariant (see above). Reform $t$ is one for the reform election in 2015 and zero for elections without the extended opening hours of polling stations. $\left(\right.$ Treat $_{i} \times$ Reform $\left._{t}\right)$ describes the interaction and thus the treatment effect of an relative increase in opening hours. For robustness tests, we will also include the interaction term between Reform $_{t}$ and other

\footnotetext{
${ }^{10}$ We also use a fractional logit model (Papke and Wooldridge 1996) because our dependent variable voter turnout is conceptually censored to a minimum of 0 and a maximum of 1 (or rather 100 percent). In our sample, voter turnout takes on values from 46 percent to 93 percent (see Table 1). Inferences do not change when we use a fractional logit instead of Ordinary Least Squares (OLS).
} 
measures such as the share of the commuting population to rule out that channels other than opening hours influenced voter turnout in 2015.

The vector $X$ includes several control variables. We include economic, sociodemographic, political and weather variables. Firstly, education and income have been shown to influence voter turnout. The Austrian government does not, however, compile education and income measures on the local level on an annual basis. Income and education are often shown to be positively correlated. We include municipal tax revenue, which reflects the local wage level as a proxy for income (and education). ${ }^{11}$ Secondly, we include socio-demographic measures. When the share of elderly, especially those in need of care, increases, voter turnout is likely to decrease. We include the share of population older than 75 years. A higher share of foreigners may also decrease voter turnout. In 2015, a large-scale influx of refugees from Balkan countries and Middle East and North African countries occurred. Voters in municipalities with a higher share of foreigners may oppose the "refugee-friendly" policy of the Austrian government by abstaining from elections. We include the share of female population to address a potential voting gender gap (women are expected to participate in elections more actively than men). Thirdly, rainfall has been shown to influence voter turnout (see, for example, Gomez et al. 2007, Knack 1994). We use hourly regional data on rainfall in Burgenland and compute the average rainfall in milliliter (liter per square meter) during opening hours (for more details see Table A.1 in the Appendix). We include a dummy for national elections and for elections after 2007 (Election liberalization) when the national parliament ratified postal voting and decreased the minimum age to vote to 16 years for all elections in Austria. $\varepsilon_{i t}$ describes an error term. We estimate the baseline difference-indifferences model using OLS with standard errors clustered at the municipal level. We also

\footnotetext{
${ }^{11}$ Municipal tax revenue is basically based on the local business tax (Kommunalsteuer) levied at a rate of 3 percent of gross wages.
} 
use standard errors robust to heteroskedasticity (Huber-White sandwich standard errors - see Huber 1967, White 1980) for robustness tests. Inferences do not change.

\section{Results}

\subsection{Baseline}

Table 2 shows our baseline results for two different panels of municipalities. Panel A (lefthand side) relates to municipalities, which fulfill the legal minimum increase in opening hours of two hours only and do not change opening hours at the regular election day. Strategic adjustment is unlikely in these municipalities in terms of an anticipated turnout effect. Panel B (right-hand side) includes all 171 municipalities of Burgenland. We show the results of models only including the explanatory variable (Treat $\times$ Reform) and fixed effects and models including all explanatory variables. The results show that inferences do not depend on including or excluding individual explanatory variables. We also show results based on the last four state elections only (columns (1) and (2), (5) and (6)) and results based on the last eight state and national elections since 2000 and the presidential election in 2016 (columns (3) and (4), (7) and (8)).

The treatment effect is statistically significant at the 1 percent level in all specifications. The numerical meaning of the effect is that doubling the opening hours of polling stations (increase in opening hours of 100 percent) increases voter turnout by 5.1 to 8.7 percentage points. Increasing the opening hours by two hours describes a relative increase in opening hours of about 35 percent - given the pre-reform mean in opening hours of about 5 hours and 41 minutes. Our findings indicate that voter turnout increased by around 1.8 to 3.0 percentage points due to the reform-induced additional two opening hours. The reform effect 
is rather substantial because voter turnout already amounted to around 80 percent before the reform.

[Table 2 about here]

The estimated coefficients of the control variables have the expected signs. The coefficient of the population size variable is statistically significant at the 1 percent level and has a negative sign. This estimate indicates that voter turnout was some 0.2 to 1.0 percentage points lower in a given municipality than in an otherwise similar municipality with 100 more inhabitants. The unemployed per capita variable has a negative sign and is statistically significant at the 10 percent level in column (4), at the 5 percent level in column (6), and at the 1 percent level in column (8). Voter turnout decreased by about 0.3 percentage points when the number of unemployed persons per 1,000 capita increased by one. Rainfall has also a negative sign and is statistically significant at the 1 percent level in all specifications. Voter turnout decreased by about 1.6 to 2.8 percentage points when there was one millimeter of rainfall during opening hours of polling stations. The coefficient for the share of elderly population is statistically significant in two specifications and has a negative sign. When the share of population older than 75 years increased by one percentage point, voter turnout decreased by around 0.3 percentage points. The coefficients of tax revenue, the share of females, and the share of foreigners have the expected signs, but lack statistical significance (the exceptions are the share of females and tax revenue in column (2) that are statistically significant at the 10 percent level).

While the share of explained variation in our estimation is reasonably large (for example, an R-squared of 0.782 in column 2 when including control variables), we cannot fully rule out a correlation with further unobserved variables. We therefore use the procedure proposed by Altonji et al. (2005) and formalized by Oster (2013) to assess the sensitivity to such biases. The test estimates the potential problems stemming from selection-on- 
unobservables from the sensitivity of the treatment coefficient to the inclusion of observable control variables (for details see Oster 2013).

We follow the application of the test in the context of panel data proposed by Gehring and Schneider (2016). We compare pooled OLS estimations with a limited set of controls (our treatment variable, and either municipal or time fixed effects) and the full set of controls as shown in columns (2), (4), (6), and (8). We use the most conservative test specification and set the unknown overall (maximum) R-squared of the model to 1, and the coefficient for proportionality, $\delta$, to 1 .

The test procedure of Oster (2013) yields a ratio $\left|\delta^{0}\right|$. The ratio measures the impact of selection-on-unobservables compared to selection-on-observables which is needed to attribute the full treatment effect to unobservables. A ratio of $\left|\delta^{0}\right|=1$ would imply that unobservables are as important as observables. The lower part of Table 2 reports the estimates of $\left|\delta^{0}\right|$ ranging from 2.3 to 133.0 . Selection-on-unobservables would have to be at least more than twice as important as selection-on-observables to harm the treatment effect, and is therefore unlikely to drive the results. We also report the identified set $[\tilde{\beta}, \beta]$. The set includes the coefficient from the estimation with our full set of controls, $\beta$, and an bias-adjusted coefficient $\tilde{\beta}$. Bias-adjustment is based on changes in the coefficient and the R-squared moving from the limited set of controls to the full set of controls (see Oster 2013 or Gehring and Schneider 2016). Table 2 shows that our identified $\beta$-set does not include the zero; our estimates therefore can be considered to be robust against a potential omitted variable bias.

\subsection{Robustness tests}

We test whether the results change when we consider different estimation specifications, subgroups, postal voting and placebo treatments. We refer to state and national elections. 
We include a quadratic treatment interaction term. The negative coefficient of the quadratic term in column (2) in Table 3 (-0.002) indicates an inverted U-shape relationship of opening hours extension and voter turnout. The maximum is reached at the 95 percentile of the distribution of the dependent variable (roughly a 70 percent increase in opening hours). The marginal gains of longer opening hours diminish. The treatment effect, however, is virtually linear for the changes in opening hours observed in our sample.

[Table 3 about here]

We use only the last pre-reform election (2013) and the first post-reform election in 2015. We exclude municipality fixed effects, include the dummy Treat and the variable Reform, and estimate a cross-section Difference-in-differences model with Pooled OLS. Inferences do not change (see column (3) in Table 3). We obtain results for Panel A (0.084) and for the entire sample (Panel B: 0.067), which are fully in line with our baseline specification (see column (1)).

We restrict our sample to municipalities, which have only one locality to examine the effect of extended opening hours in a more homogenous sample. In municipalities with multiple localities, the second election day was held in only one out of all localities. ${ }^{12}$ Voters of the other localities were allowed to vote in the "ballot box locality," but have to travel by car to do so. In municipalities with one locality only, mobility issues can be ruled out. Column (4) in Table 3 shows that inferences do not change for the sub-sample of municipalities with only one locality. Thus, geographical fragmentation does not drive results. $^{13}$

\footnotetext{
${ }^{12}$ The municipalities of Mattersburg and Rotenturm an der Pinka were exceptions: The second election day was held in two localities each.

${ }^{13}$ For municipalities with more than one locality, we also find a significant and positive treatment effect on voter turnout in panel B. In panel A, the sample gets very small (27 municipalities). The coefficient does not turn out to be statistically significant at the conventional levels (p-value: 0.15 ).
} 
Postal voting was introduced by federal law in 2007. Municipal voter turnout figures do not include postal voting because postal votes are collected at the district level. Postal voting, however, is only hardly important in Burgenland. Between 2008 and 2015, about 5 percent of the electorate chose postal voting. In any event, we add district postal voting voter turnout to "regular" municipal voter turnout. The treatment effect gets slightly smaller compared to our baseline specification, but remains statistically significant at the 1 percent level (column (5) in Table 3).

Columns (6) and (7) in Table 3 show the results for two different placebo treatments. We re-assigned real opening hours to municipalities quasi-randomly by alphabetical order. As expected, the alphabetical placebo treatment does not turn out to be statistically significant. We also include the interaction terms of fixed time effects and our treatment measure (see Finkelstein 2007). The reference category is the last pre-reform election in 2013; Treat $\times$ Reform is identical to the interaction of the 2015 time effect and the treatment measure. In Panel B, the results do not show that any of the pre-reform periods differ significantly from the 2013 election (reference category). Only our interaction term of interest is statistically significant. Remarkably, even the interaction effect for the 2016 presidential election (no extended opening hours) does not turn out to be statistically significant. Hence, we conclude that there was a unique treatment in the reform year 2015. We also do not observe a significant impact of our variable of interest in non-treatment periods in Panel A, with the exception of the long-gone 2002 elections.

\subsection{Heterogeneous treatment effects}

We investigate whether the treatment effect varies among treatment intensity. Table 3, column (2) already indicated that the effect of longer opening hours on voter turnout may somehow diminish above a certain threshold. Two additional opening hours may especially 
increase voter turnout in municipalities with short opening hours, but hardly do so in municipalities with long opening hours. Figure 4 indicates that municipalities with long prereform opening hours ( $\geq 7$ hours) hardly experienced higher voter turnout. We split the sample into the municipalities with long pre-reform opening hours (low treatment intensity group), and the remaining municipalities (high treatment intensity group). The results in Table 4 columns (2) and (4) show that the treatment effect does not turn out to be statistically significant in the low treatment intensity group ( $\geq 7$ hours). The large point estimate for panel A is mainly caused by the small number of observed municipalities $(n=24)$. By contrast, the treatment effect is statistically significant for the high treatment intensity group of municipalities at least in the full sample with pre-reform opening hours of less than 7 hours (column (3)). The treatment effect slightly fails statistical significance in column (1), an estimate, which is based on a quite small sample. Inferences do not change when we split the sample into municipalities with quite long opening hours ( $\geq 8$ and 9 hours) and others. When we split the sample at the median (6 hours), the treatment effect does not turn out to be statistically significant in the low treatment intensity group and slightly lacks statistical significance at the 10 percent level in the high treatment group in panel B (p-value: 0.104). Extending opening hours particularly affected municipalities with lower pre-reform voting opportunities.

[Table 4 about here]

\section{Excluding other channels}

Opening hours of polling stations in Burgenland were extended by introducing a second election day (Friday evening), and only one ballot box per municipality had to be opened. All municipalities had to deal with the new electoral institutions. Year fixed-effects should therefore capture all systematic differences influencing all municipalities in the reform year 
2015 compared to other election years. However, we also examine whether other measures such as the time schedule, which influence the municipalities asymmetrically, drive the results.

Table 5 compares our baseline results (column (1)) to models, which also include a variable for three different additional channels: (1) Friday evening voting, (2) the second election day, and (3) a lack of ballot boxes (columns (2) to (5)). Firstly, one may conjecture that Friday evening voting instead of longer opening hours of polling stations may have increased voter turnout. Friday evening voting targets commuters. Commuters may stop on their way home at the ballot box to cast their vote. Non-commuters, by contrast, are not more likely to pass the ballot box on Friday evenings than at any other times. Friday evening voting therefore increases the accessibility of polling stations for commuters to a larger extent than for non-commuters. Therefore, Friday evening voting may have affected municipalities differently, depending on the local share of commuters: the larger the share of commuters the more appreciated is Friday evening voting. We include the municipal ratio of commuters and electorate, interacted with the reform period. If the effects in the reform election (2015) are driven by Friday evening voting, the interaction term of the share of commuters and the reform period should have a positive effect on voter turnout. We again include year fixed effects, which control for symmetric effects of voting on a Friday evening influencing all municipalities in the same way. However, the share of commuters interacted with the reform period does not turn out to be statistically significant (column (2)). Moreover, inferences of our variable measuring changes in opening hours (Treat $\times$ Reform) do not change.

[Table 5 about here]

Secondly, the introduction of a second election day might have influenced "busy" municipalities with a high share of working voters. A second election day increases voting opportunities for non-working voters less than for workers facing severe time constraints. In 
this case, the reform may have had different effects on turnout in municipalities with a high share of working voters compared to municipalities with a high share of non-working voters (e.g., pupils, or pensioners). If this is true, we would expect a positive effect of the local workforce in the reform period on voter turnout. The local ratio of workforce and electorate interacted with the reform period, however, does also not turn out to be statistically significant (column (3)).

Thirdly, in 97 percent of all municipalities with multiple localities, the second election day was held in one locality only (main locality of the municipality). Voters of other localities have to go by car to the "central” ballot box in the main locality if they want to cast their vote on the second election day. This asymmetry in voting opportunities may have disadvantaged municipalities where a large share of population lives outside the main locality. We address this issue in two different ways. Firstly, we interact the reform period dummy with the municipal share of electorate living in localities without an own ballot box on the second election day. Secondly, we compute the (great circle) distance to the next polling station at the second election day for each locality. ${ }^{14}$ The municipal average distance is the mean of all localities. Column (4) and (5) in Table 5 shows that the absence of a ballot box in a locality did not affect voter turnout: the municipal share of electorate that did not have access to an ballot box in their own locality at the second election day, and the average distance to a ballot box on the second election day does not turn out to be statistically significant in Panel A or in Panel B.

In all specifications in Table 5, inferences regarding the effect of extended opening hours on voter turnout do not change. Other channels than the extension of opening hours are therefore unlikely to drive our results.

\footnotetext{
${ }^{14}$ We assume the distance to the next polling station to be 0 in localities with one ballot box on the second election day.
} 
We use regional variation in electoral institutions between Austrian states to exclude spurious findings resulting from any other unobservable idiosyncratic event in the election year 2015. In 2015, state and local elections were held in Burgenland and in the Austrian state of Upper Austria, which are not direct geographical neighbors. In contrast to Burgenland, the state government of Upper Austria did not force municipalities to extend opening hours of polling stations. There are, however, many more differences between the 2015 state elections in Burgenland and Upper Austria. Estimating a difference-in-differences model exploiting that Burgenland reformed electoral institutions in 2015, but Upper Austria did not do so, is not suitable. ${ }^{15}$ In any event, we should not expect voter turnout to differ by pre-treatment opening hours in Upper Austria because there was basically no change in opening hours. In fact, Figure 6 shows no differences in voter turnout in the pseudo-treatment period. This contrasts with Figure 4 showing that voter turnout in Burgenland in the reform period differs by pre-treatment opening hours. We conclude that our results for Burgenland are also not driven by idiosyncratic events in the election year 2015.

[Figure 6 about here]

\section{Party vote shares}

We examine to what extent longer opening hours of polling stations influenced vote shares of the four main parties in Austria: the leftwing SPÖ, the conservative ÖVP, the populist rightwing FPÖ, and the Green Party (Greens). Reverse causality between supporting the

\footnotetext{
${ }^{15}$ The state elections in Burgenland and Upper Austria took place on 31 May 2015 and 27 September 2015, and the circumstances in both states differed a great deal, which we cannot address in a differences-in-differences model. In particular, the European refugee crisis was in full swing on 27 September 2015 (it was much less of an issue on 31 May 2015), Upper Austria had state and local elections taking place on the same day (Burgenland just had state elections). Trends in voter turnout in Upper Austria and Burgenland differed prior to 2015 (and continue to do so). Estimating a differences-in-differences model would not help to disentangle whether voter turnout increased in Burgenland because of a second election day or the pure increase in opening hours either. To examine the causal effect of increasing opening hours on voter turnout, it is therefore more useful to exploit variation within Burgenland over time and elaborate on treatment intensity (as done by Finkelstein 2007 and others).
} 
reform and voters rewarding/punishing individual parties is unlikely because almost all parties (except four MPs of the populist rightwing FPÖ and the homeland party "Liste Burgenland”) voted for the electoral reform in the state parliament in 2014 (see Section 3.1).

We use the vote shares of each individual party as dependent variable and estimate the econometric model described in section $3 .^{16}$ The upper part of Table 6 shows that the vote share of the conservative ÖVP significantly decreased by 0.9 to 1.2 percentage points when opening hours were extended by 10 percent (Panel A and Panel B). The extension of opening hours by two hours (which is equivalent an relative increase of 35 percent) thus gave rise to a decrease of 3.2 to 4.2 percentage points of the conservative party vote share, a numerically important effect. Vice versa, the other three main parties benefited from longer opening hours. The vote shares of the more leftwing Green party (Panel A), of the leftwing SPÖ (Panel B), and of the rightwing FPÖ (Panel A and B) increased by about $0.27,0.72$ and 0.38 to 0.52 percentage points when opening hours increased by 10 percent. The results for the Greens and the SPÖ are in line with related studies (e.g., Fujiwara 2015). At first glance, the effect of longer opening hours on the vote share of the populist rightwing FPÖ may not be intuitive. Since the 2000s, however, many blue-collar workers who were traditionally inclined towards the leftwing SPÖ, have voted for the populist rightwing FPÖ. SPÖ and FPÖ voters responded in a similar manner to incentives induced by electoral institutions such as longer opening hours. These results help to explain why conservative parties may oppose longer opening hours (an example being Germany’s Christian Conservatives when the general secretary of the German leftwing SPD proposed to increase opening hours in December 2014).

\section{[Table 6 about here]}

\footnotetext{
${ }^{16}$ We exclude the presidential election of 2016 because direct elections are not comparable with parliamentary elections in terms of participating parties.
} 
We tested whether the results are robust. Inferences do not change when we use state elections only (Table 6, lower part). The longer opening hours of polling stations decreased the ÖVP vote shares and increased the SPÖ and FPÖ vote shares (Panel B). In panel A with the strict treatment definition, the longer opening hours of polling stations increased the vote shares of all parties, with the exception of the vote share of the conservative ÖVP.

Including or excluding control variables does not change the inferences regarding the treatment variable (see Table A.2 in the Appendix). We used municipalities with one locality only. In panel B, longer opening hours decreased the ÖVP vote share and increased the SPÖ vote share. The treatment effects lack statistical significance when we use the vote shares of other parties as a dependent variable. In the subsample of one-locality municipalities (panel A), however, the treatment effects lack statistical significance most probably because of the small number of observations. We focused on municipalities with high treatment intensity (pre-reform opening hours of polling stations of less than 7 hours, see section 4.3). In both panels A and B, we find substantial negative effects of longer opening hours on the ÖVP vote share. In panel A, we observe a significant increase in the SPÖ vote share. Altogether, the results suggest that longer opening hours of polling stations mobilized voters of individual parties in different ways. Voters of the social democratic SPÖ and of the populist rightwing FPÖ (both parties attract blue-collar workers) were more active in participating in the 2015 state elections due to the longer opening hours of polling stations. By contrast, longer opening hours decreased the vote share of the conservative ÖVP, whose voters are expected to be more disciplined and to have a stronger sense of civic duty than voters of the leftwing SPÖ and the populist rightwing FPÖ. 


\section{Conclusion}

Scholars have examined whether electoral institutions intended to increase voter turnout (such as compulsory voting) actually work. Yet, there have been no studies identifying a causal effect of (extending) opening hours on voter turnout. We estimate the causal effect of longer opening hours of polling stations on voter turnout based on a natural experiment in the Austrian state of Burgenland. The results show that extending opening hours by 10 percent causes the voter turnout to increase by around 0.5 to 0.9 percentage points. An important question is to what extent our findings might be valid for other countries and types of elections.

Voter turnout in Austria is suitable for comparison with voter turnout in other OECD countries (Hoffman et al. 2016). Average pre-reform opening hours of 5 hours and 41 minutes in Burgenland were, however, short compared to those of national elections and other federal states. Polling stations open for about 10 hours in national elections in many OECD countries, for 10 hours in German state elections and for as long as 12 hours in US state elections. The opening hours in Burgenland, however, are highly comparable with the opening hours of other rural Austrian states (6 hours and 45 minutes on average). All other eight Austrian states open their polling stations for about 7 hours and 9 minutes on average (the opening hours of the urban state of Vienna is far above average at 10 hours). There are also quite short opening hours of polling stations in Austria's neighboring countries Liechtenstein and Switzerland (about 4 hours in national elections). Extending opening hours of polling stations might also be a more "soft" substitute for compulsory voting, for example, in Belgium and Luxemburg, where polling stations open for 5 to 6 hours in national elections. We therefore believe that the effects estimated based on the reform in Burgenland certainly help to predict potential effects in other countries and states. 
Relating our findings to opening hours and voter turnout in national and state elections in other OECD countries and assuming that similar effects would emerge gives rise to the following predictions: in the United States, for example, voter turnout would increase by around 0.4 to 0.7 percentage points in national elections if opening hours were to be extended by one hour, and in the United Kingdom by around 0.3 to 0.6 percentage points. In Germany and Italy voter turnout would increase by 0.5 to 0.9 and 0.2 to 0.4 percentage points. These effects are large. Politicians who wish to draw on these findings need to consider, of course, that stimulating voter turnout will become more difficult the larger the initial level of voter turnout is. Enhancing participation in elections by extending the opening hours of polling stations remains a question to what extent politicians and voters believe that the benefits of higher voter turnout overcompensate for additional costs of longer opening hours.

The results also show that the vote share of the conservative party ÖVP decreased and the vote shares of the leftwing SPÖ and the populist rightwing FPÖ somewhat increased in the course of longer opening hours. Previous studies also showed that other electoral institutions such as introducing compulsory voting benefitted leftwing parties. The chance of extending the opening hours of polling stations in other countries is thus also likely to depend on political preferences and majorities. Political self-interest also determines whether there is support for policies that increase voter turnout such as extending the opening hours of polling stations. We conjecture that the most important reason for low voter turnout in industrialized democracies is probably disenchantment with politics. Many voters are concerned about the quality of politicians and about whether politicians' preferences are decoupled from voters' preferences. Some voters even believe that politicians are corrupt. When politicians desire to increase voter turnout, they seem well advised to enhance political knowledge (see, for example, Hodler et al. 2015, Lopez De Leon and Rizzi 2014) and explain that they do not 
seek public office to line their pockets. Voters are likely to participate in elections when they perceive politicians to be trustworthy (e.g. Putnam 1993, Elinder et al. 2015). ${ }^{17}$

\footnotetext{
${ }^{17}$ A special case was the family scandal of Bavarian MPs in 2013 (Kauder and Potrafke 2015).
} 


\section{References}

Acemoglu, D., Autor, D. H., Lyle, D., 2004. Women, war, and wages: The effect of female labor supply on the wage structure at midcentury. Journal of Political Economy 112, 497-551.

Altonji, J., Elder, T., Taber, C. R., 2005. Selection on observed and unobserved variables: Assessing the effectiveness of catholic schools. Journal of Political Economy 113, 151-184.

Arnold, F., Freier, R., 2016. Only conservatives are voting in the rain: Evidence from German local and state elections. Electoral Studies 41, 216-221.

Artés, J., 2014. The rain in Spain. Turnout and partisan voting in Spanish elections. European Journal of Political Economy 34, 126-141.

Bechtel, M. M., Hangartner, D., Schmid, L., 2015. Compulsory voting, habit formation, and political participation, mimeo.

Bechtel, M. M., Hangartner, D., Schmid, L., 2016. Does compulsory voting increase support for leftist policy? American Journal of Political Science 60, 752-767.

Bechtel, M. M., Schmid, L., 2016. Direct democracy, postal voting, and the composition of turnout, mimeo.

Besley, T., Case, A., 2003. Political institutions and policy choices: Evidence from the United States. Journal of Economic Literature 41: 7-73.

Brennan, G., Brooks, M., 2013. Expressive voting. Reksulak, M., Razzolini, L., and Shughart, W. F. II (Eds.), The Elgar Companion to Public Choice. Second edition. Edward Elgar, Cheltenham UK, 111-126.

Brennan, G., Hamlin, A., 2000. Democratic Devices and Desires. Cambridge University Press, Cambridge UK.

Burden, B. C., Canon, D. T., Mayer, K. R., Moynihan, D. P., 2014. Election laws, mobilization, and turnout: The unanticipated consequences of election reform. American Journal of Political Science 58, 95-109.

Cancela, J., Geys, B., 2016. Explaining voter turnout: A meta-analysis of national and subnational elections, Electoral Studies 42, 264-275. 
Card, D., 1992. Using regional variation in wages to measure the effects of the federal minimum wage. Industrial and Labor Relations Review 46, 22-37.

Dee, T. S., 2004. Are there civic returns to education? Journal of Public Economics 88, 16971720.

Downs, A., 1957. An economic theory of political action in a democracy. Journal of Political Economy 65, 135-150.

Dropp, K. A., 2012. Polling place hours and voter turnout, mimeo. Stanford University.

Elinder, M., Jordahl, H., Poutvaara, P., 2015. Policies, promises, and pocketbook voting. European Economic Review 75, 177-194.

Ferwerda, J., 2014. Electoral consequences of declining participation: A natural experiment in Austria. Electoral Studies 35, 242-252.

Finkelstein, A., 2007. The aggregate effects of health insurance: Evidence from the introduction of Medicare, Quarterly Journal of Economics 122, 1-37.

Fowler, A., 2013. Turnout matters: Evidence from compulsory voting in Australia. Quarterly Journal of Political Science 8, 1-24.

Frey, B. S., 1971. Why do high-income people participate more in politics? Public Choice 11, 101-105.

Fujiwara, T., 2015. Voting technology, political responsiveness, and infant health: Evidence from Brazil. Econometrica 83, 423-464.

Funk, P., 2010. Social incentives and voter turnout: Evidence from the Swiss mail ballot system. Journal of the European Economic Association 8, 1077-1103.

Gehring, K., Schneider, S. A., 2015. Towards the greater good? EU commissioners' nationality and budget allocation in the European Union, ETH and University of Zurich CIS Working Paper, No. 86 (February 2016).

Gerber, A. S., Green, D., Larimer, C., 2008. Social pressure and voter turnout: Evidence from a large-scale field experiment. American Political Science Review 102, 33-48.

Geys, B., 2006. Explaining voter turnout: A review of aggregate-level research. Electoral Studies 25, 637-663.

Glaeser, E. L., Ponzetto, G., Shleifer, A., 2006. Why does democracy need education? Journal of Economic Growth 12, 77-99. 
Gomez, B. T., Hansford, T. G., Krause, G. A., 2007. The Republicans should pray for rain: Weather, turnout and voting in U.S. presidential elections. Journal of Politics 69, 649663.

Hamlin, A., Jennings, C., 2011. Expressive political behaviour: Foundations, scope and implications. British Journal of Political Science 41, 645-670.

Hansford, T. G., Gomez, B. T., 2010. Estimating the electoral effects of voter turnout. American Political Science Review 104, 268-288.

Highton, B., 1997. Easy registration and voter turnout. Journal of Politics 59, 565-575.

Hillman, A. L., 2010. Expressive behavior in economics and politics. European Journal of Political Economy 26, 403-418.

Hodler, R., Luechinger, S., Stutzer, A., 2015. The effects of voting costs on the democratic process and public finances. American Economic Journal: Economic Policy 7, 141171.

Hoffman, M., Léon, G., Lombardi, M., 2016. Compulsory voting, turnout, and government spending: Evidence from Austria. NBER Working Paper 22221.

Holbein, J. B., Hillygus, D. S., 2016. Making young voters: the impact of preregistration on youth turnout. American Journal of Political Science 60, 364-382.

Huber, P. J., 1967. The behavior of maximum likelihood estimates under nonstandard conditions. Proceedings of the Fifth Berkeley Symposium on Mathematical Statistics and Probability, 221-233.

Hummel, P., Knight, B., 2015. Sequential or simultaneous elections? A welfare analysis. International Economic Review 56, 851-887.

Jaitman, L., 2013. The causal effect of compulsory voting laws on turnout: Does skill matter? Journal of Economic Behavior \& Organization 92, 79-93.

Kasara, K., Suryanarayan, P., 2015. When do the rich vote less than the poor and why? Explaining turnout inequality across the world. American Journal of Political Science 59, 613-627.

Kauder, B., Potrafke, N., 2015. Just hire your spouse! Evidence from a political scandal in Bavaria. European Journal of Political Economy 38, 42-54. 
Knack, S., 1992. Civic norms, social sanctions and voter turnout. Rationality and Society 4, 133-156.

Knack, S., 1994. Does rain help the Republicans? Theory and evidence on turnout and the vote. Public Choice 79, 187-209.

Lijphart, A., 1997. Unequal participation: Democracy's unresolved dilemma. American Political Science Review 91, 1-14.

Lind, J. T., 2013. Rainy day politics - An instrumental variables approach to the effect of parties on political outcomes. Paper presented at the Silvaplana Workshop on Political Economy, Pontresina.

Lopez De Leon, F. L., Rizzi, R., 2014. A test for the rational ignorance hypothesis: Evidence from a natural experiment in Brazil. American Economic Journal: Economic Policy 6, 380-398.

Luechinger, S., Rosinger, M., Stutzer, A., 2007. The impact of postal voting on participation: Evidence for Switzerland. Swiss Political Science Review 13, 167-202.

Milligan, K., Moretti, E., Oreopoulos, P., 2004. Does education improve citizenship? Evidence from the United States and the United Kingdom. Journal of Public Economics 88, 1667-1695.

Morton, R. B., Muller, D., Page, L., Torgler, B., 2015. Exit polls, turnout, and bandwagon voting: Evidence from a natural experiment. European Economic Review 77, 65-81.

Mueller, D., Stratmann, T., 2003. The economic effects of democratic participation. Journal of Public Economics 87, 2129-2155.

Nunn, N., Wantchekon, L., 2011. The slave trade and the origins of mistrust in Africa. American Economic Review 101, 3221-3252.

Oster, E., 2013. Unobservable selection and coefficient stability: Theory and validation, NBER Working Paper 19054.

Papke, L. E., Wooldridge, J. M., 1996. Econometric methods for fractional response variables with an application to 401(K) plan participation rates. Journal of Applied Econometrics 11, 619-632.

Putnam, R. D., 1993. Making democracy work: Civic traditions in modern Italy. Princeton University Press, Princeton. 
Riker, W. H., Ordeshook, P.C., 1968. A theory of the calculus of voting. American Political Science Review 62, 25-42.

Statistics Canada (2011). Reasons for not voting in the May 2, 2011 federal election, http://www.statcan.gc.ca/daily-quotidien/110705/dq110705a-eng.htm, May 2011 (accessed on 12 January 2016).

Tingsten, H., 1937. Political behavior: Studies in election statistics. P.S. King \& Son, London.

White, H., 1980. A heteroskedasticity-consistent covariance matrix estimator and a direct test for heteroskedasticity. Econometrica 48, 817-838.

Wolfinger, R. E, Rosenstone, S. J., 1980. Who votes? Yale University Press, New Haven and London. 


\section{Figures}

Figure 1. OPENING HOURS AND Voter TURNOUT IN NATIONAL ELECTIONS

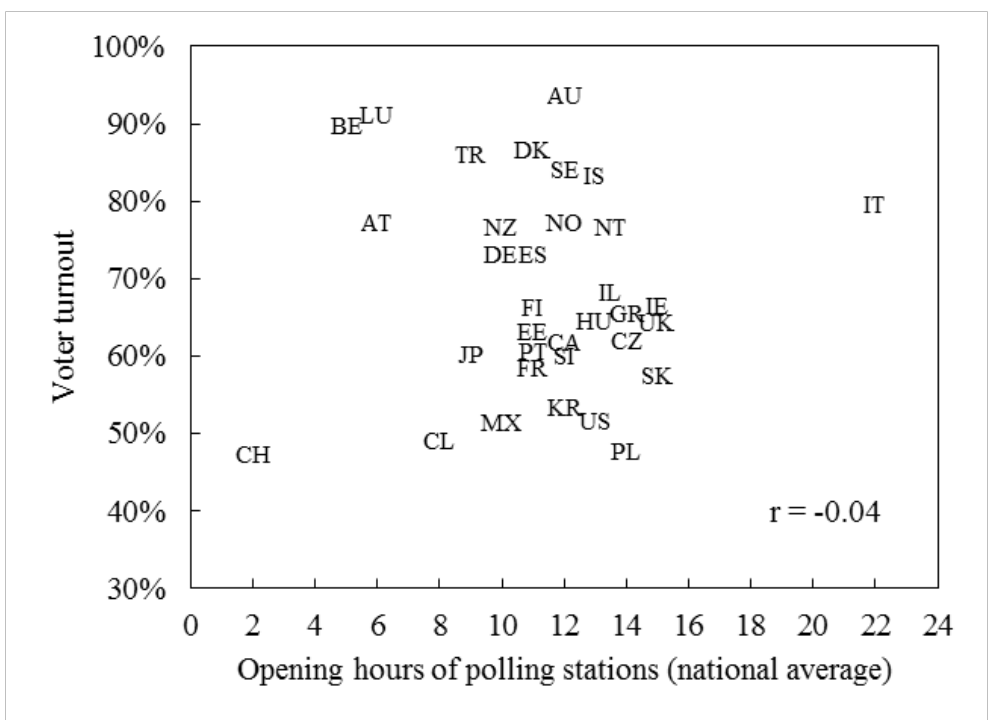

Notes: The figure shows mean opening hours of polling stations and voter turnout for 34 OECD countries over the period 2002-2015. In cases of regional differences we compute the national average of opening hours. Voter turnout: Mean of the last three national elections (CL: last election only because compulsory voting was abolished in 2013). Sources: Data on voter turnout are obtained from the International Institute for Democracy and Electoral Assistance (International IDEA). Data on opening hours are self-compiled. 
Figure 2. Opening Hours of POLLing Stations IN BuRgenland, 2008-2016

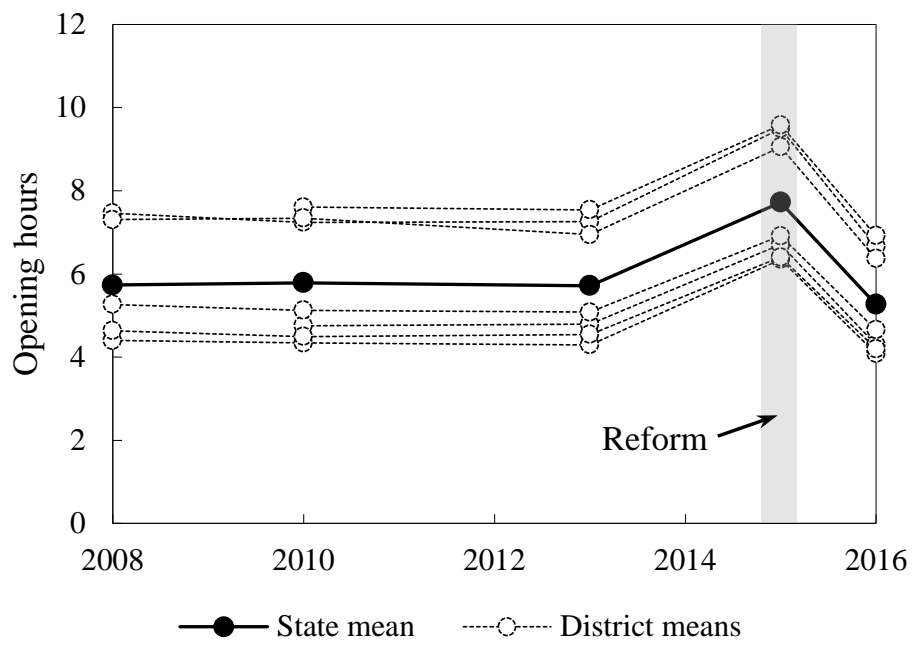

Notes: The figure shows the mean of opening hours of polling stations in Burgenland for the state elections in 2010 and 2015, for the national elections in 2008 and 2013, and for the presidential election in 2016. The solid line describes the overall Burgenland mean in opening hours. Dashed lines describe mean opening hours of the seven districts of Burgenland. The cities of Eisenstadt and Rust were assigned to the district of EisenstadtUmgebung. 2008: Data for the districts of Jennersdorf and Mattersburg missing. 2010: Data for the district of Güssing missing; replaced by opening hours in 2009 European election. 
Figure 3. PRE-REFORM Voter TURNOUT AND CHANGE IN OPENING HOURS (2010-2015)

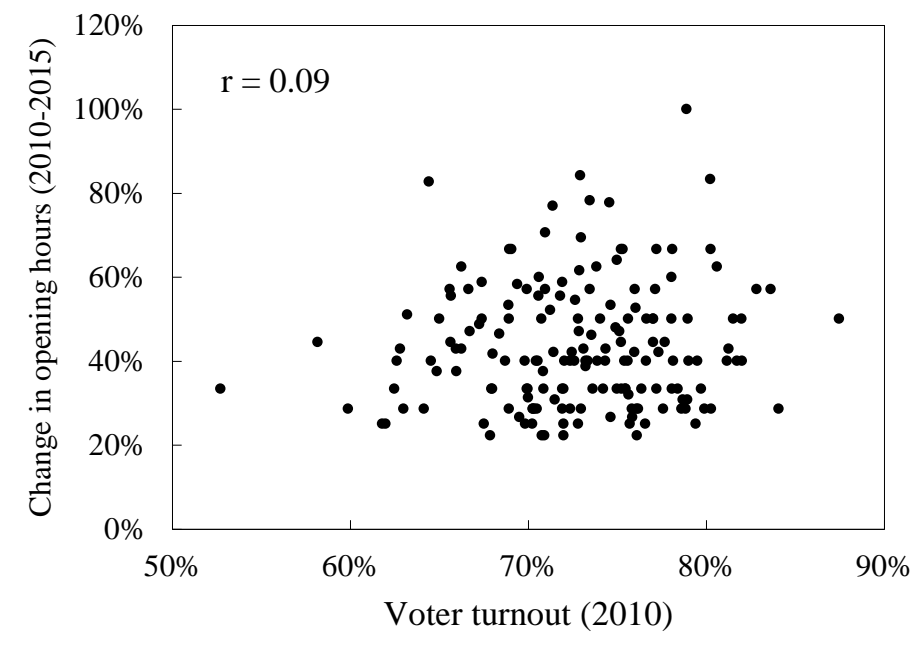

Notes: The figure plots pre-reform voter turnout (state election 2010) against the relative change in opening hours from 2010 to 2015 (municipal level). See Figure A.1 in the Appendix for plots of other pre-reform characteristics. 
Figure 4. Voter TuRnout in Burgenland By PRe-Reform Opening Hours, 2000-2016

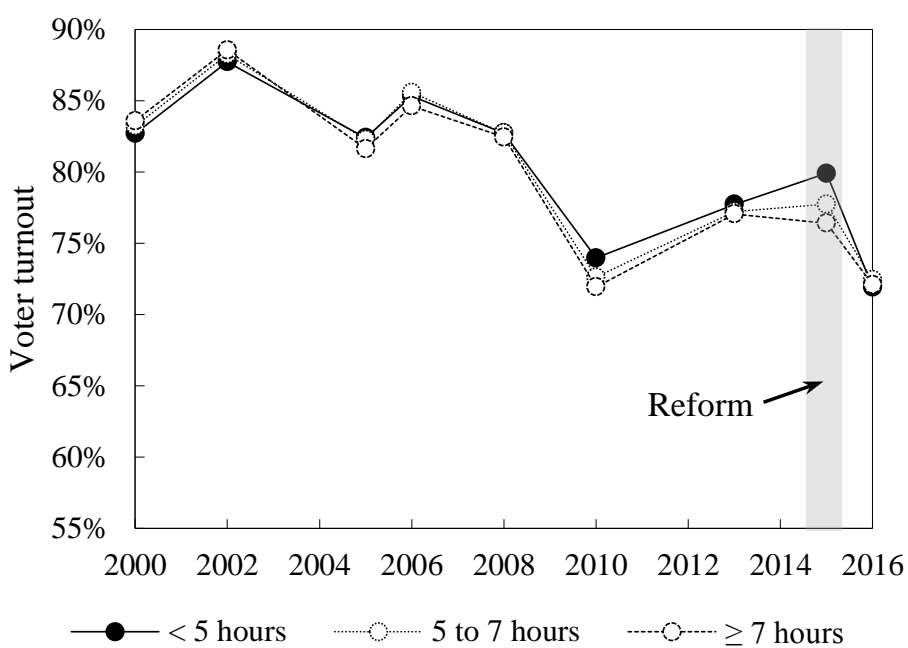

Notes: The figure shows mean voter turnout in Burgenland for the state elections in 2000, 2005, 2010 and 2015, for the national elections in 2002, 2006, 2008 and 2013, and for the presidential election in 2016. The lines describe voter turnout for the roughly lower 33 percent quantile ( $<5$ hours, solid line), center 33 percent quantile (5 to 7 hours, dotted line) and upper 33 percent quantile ( $\geq 7$ hours, dashed line) in terms of pre-reform opening hours (state election 2010). 
Figure 5. CHANGE IN OPENING HOURS AND VOTER TURNOUT

Change in opening hours 2010-2015 (in percent)

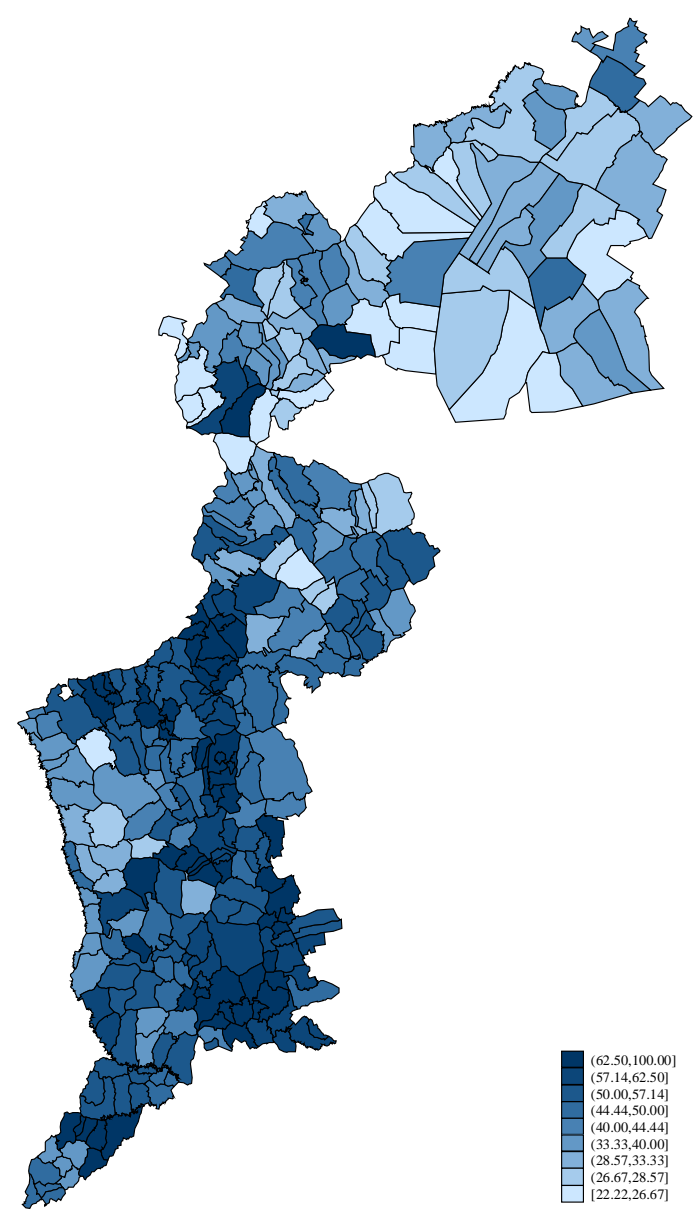

Change in voter turnout 2010-2015 (in percent)

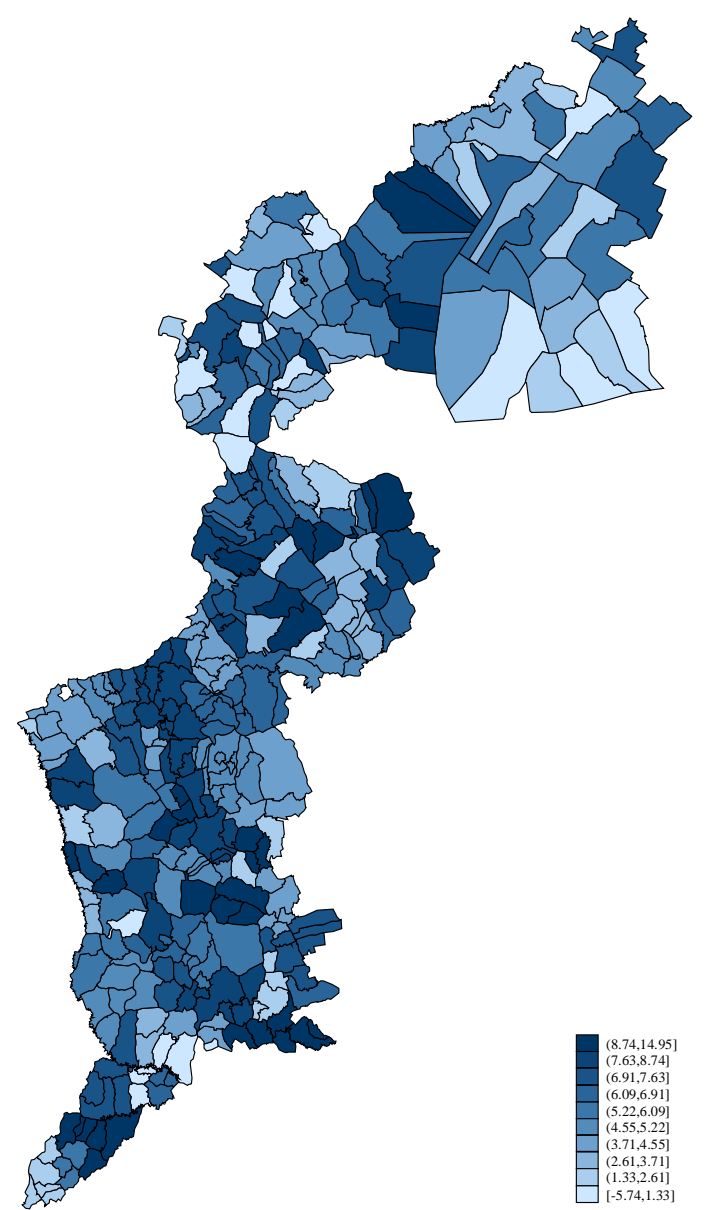

Notes: The left-hand map shows the relative increase in opening hours of polling stations in municipalities from 2010 to 2015 in Burgenland. The right-hand map shows the relative increase in voter turnout in the state elections from 2010 to 2015. 
Figure 6. Voter Turnout in Upper Austria By (Pseudo) Pre-Reform OPEning Hours, 1999-2016

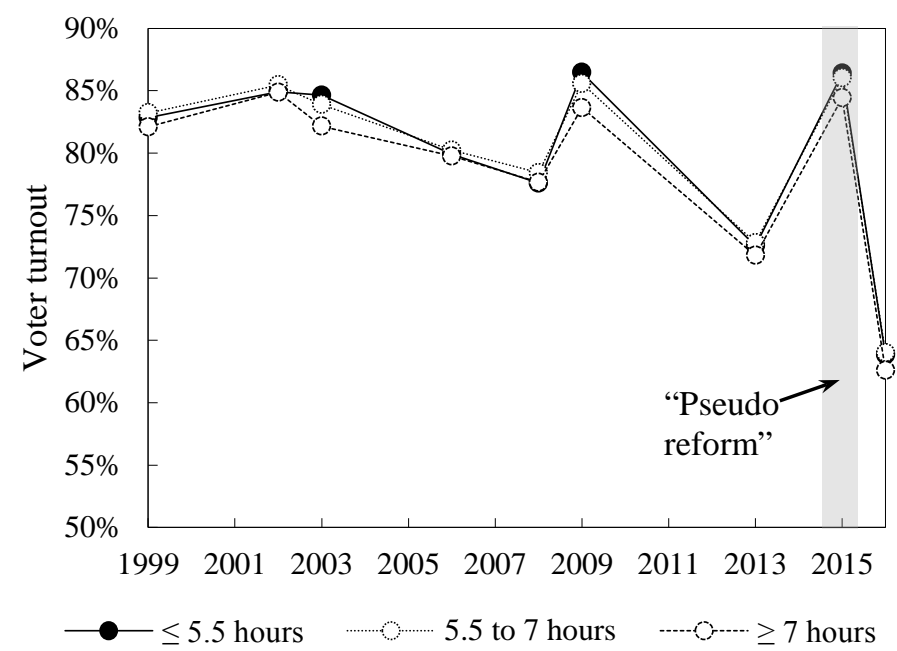

Notes: The figure shows mean voter turnout in Upper Austria for the state elections in 2003, 2009 and 2015, for the national elections in 1999, 2002, 2006, 2008 and 2013, and for the presidential election in 2016. The lines describe voter turnout for the roughly lower 33 percent quantile $(<5.5$ hours, solid line), center 33 percent quantile (5.5 to 7 hours, dotted line) and upper 33 percent quantile ( $\geq 7$ hours, dashed line) in terms of prereform opening hours (state election 2010). 


\section{Tables}

TABLE 1. DESCRIPTIVES

\begin{tabular}{|c|c|c|c|c|c|c|c|c|c|c|}
\hline & \multicolumn{5}{|c|}{$\begin{array}{c}\text { Panel A } \\
\text { (Strict sample) }\end{array}$} & \multicolumn{5}{|c|}{$\begin{array}{c}\text { Panel B } \\
\text { (Full sample) }\end{array}$} \\
\hline & Obs. & Mean & Std. Dev. & Min & $\operatorname{Max}$ & Obs. & Mean & Std. Dev. & Min & Max \\
\hline & (1) & $(2)$ & (3) & (4) & (5) & (6) & (7) & (8) & (9) & $(10)$ \\
\hline Voter turnout & 747 & 80.76 & 6.34 & 59.86 & 93.18 & 1,539 & 80.17 & 6.72 & 45.65 & 93.23 \\
\hline SPÖ vote share $e^{a}$ & 664 & 45.74 & 11.58 & 9.73 & 78.98 & 1,368 & 45.62 & 11.32 & 9.73 & 84.78 \\
\hline ÖVP vote share $e^{a}$ & 664 & 35.16 & 12.14 & 10.41 & 77.70 & 1,368 & 34.57 & 11.86 & 6.52 & 77.70 \\
\hline FPÖ vote share ${ }^{a}$ & 664 & 10.85 & 6.06 & 0.40 & 33.87 & 1,368 & 10.93 & 6.07 & 0 & 33.87 \\
\hline Greens vote share ${ }^{a}$ & 664 & 4.13 & 1.87 & 0 & 11.73 & 1,368 & 4.56 & 2.35 & 0 & 17.79 \\
\hline Other parties vote share ${ }^{a}$ & 664 & 4.11 & 4.10 & 0 & 25.54 & 1,368 & 4.32 & 4.61 & 0 & 41.60 \\
\hline Treat & 747 & 39.65 & 12.81 & 22.22 & 84.21 & 1,539 & 43.47 & 14.78 & 22.22 & 100.00 \\
\hline Reform & 747 & 0.11 & 0.31 & 0 & 1 & 1,539 & 0.11 & 0.31 & 0 & 1 \\
\hline Treat $\times$ Reform & 747 & 4.41 & 13.18 & 0 & 84.21 & 1,539 & 4.83 & 14.53 & 0 & 100.00 \\
\hline Population & 747 & 1,213 & 656 & 316 & 4,473 & 1,539 & 1,652 & 1,411 & 58 & 14,226 \\
\hline Share of female & 747 & 50.68 & 1.32 & 46.16 & 54.27 & 1,539 & 50.89 & 1.36 & 45.19 & 60.29 \\
\hline Share of foreigners & 747 & 4.58 & 3.03 & 0.23 & 25.68 & 1,539 & 4.80 & 3.39 & 0 & 42.93 \\
\hline Share of population $>75$ years & 747 & 9.56 & 2.30 & 4.45 & 17.36 & 1,539 & 9.61 & 2.20 & 3.56 & 18.57 \\
\hline Unemployed per 1,000 capita & 747 & 2.44 & 1.65 & 0.28 & 8.57 & 1,539 & 2.37 & 1.61 & 0 & 9.30 \\
\hline Tax revenue $e^{b}$ & 747 & 0.20 & 0.16 & 0.03 & 1.01 & 1,539 & 0.22 & 0.18 & 0.02 & 1.46 \\
\hline Rainfall $^{c}$ & 747 & 0.04 & 0.11 & 0 & 1.69 & 1,539 & 0.04 & 0.11 & 0 & 1.69 \\
\hline National election & 747 & 0.56 & 0.50 & 0 & 1 & 1,539 & 0.56 & 0.50 & 0 & 1 \\
\hline Election liberalization $^{d}$ & 747 & 0.56 & 0.50 & 0 & 1 & 1,539 & 0.56 & 0.50 & 0 & 1 \\
\hline Share of commuters & 747 & 41.19 & 6.18 & 27.23 & 55.10 & 1,539 & 40.22 & 6.20 & 23.76 & 60.42 \\
\hline Share of workforce & 747 & 53.25 & 6.10 & 40.05 & 68.71 & 1,539 & 53.15 & 6.08 & 32.34 & 69.22 \\
\hline Share of voters without own ballot box & 747 & 14.41 & 23.17 & 0 & 86.70 & 1,539 & 14.93 & 23.94 & 0 & 86.70 \\
\hline
\end{tabular}

Notes: The table shows the descriptives of a sample of municipalities which fulfill the minimum requirement of two additional opening hours only and do not change opening hours on the regular election day between 2010 and 2015 (Panel A) in columns (1)-(5), and for the full sample in columns (6)-(10). The panels include data on 83 (171) municipalities for nine state, national and presidential elections between 2002 and 2016. a) No party vote shares for the presidential election in 2016. b) Total municipal tax revenue in Euro per 1,000 capita. c) Milliliter (liter per square meter) per opening hour. d) We include a dummy for elections after 2007 (2008, 2010, 2013, 2015, and 2016). National parliament ratified postal voting and decreased the minimum age to vote to 16 years for all elections in Austria in 2007. 
TABLE 2. BASELINE REsUltS

\begin{tabular}{|c|c|c|c|c|c|c|c|c|}
\hline & \multicolumn{8}{|c|}{ Dependent variable: Voter turnout } \\
\hline & \multicolumn{4}{|c|}{$\begin{array}{c}\text { Panel A } \\
\text { (Strict sample) }\end{array}$} & \multicolumn{4}{|c|}{$\begin{array}{c}\text { Panel B } \\
\text { (Full sample) }\end{array}$} \\
\hline & \multicolumn{2}{|c|}{ State elections } & \multicolumn{2}{|c|}{$\begin{array}{l}\text { State and national } \\
\text { elections }\end{array}$} & \multicolumn{2}{|c|}{ State elections } & \multicolumn{2}{|c|}{$\begin{array}{l}\text { State and national } \\
\quad \text { elections }\end{array}$} \\
\hline & (1) & $(2)$ & (3) & (4) & (5) & (6) & (7) & (8) \\
\hline Treat $\times$ Reform & $\begin{array}{c}0.081 * * * \\
(0.026)\end{array}$ & $\begin{array}{c}0.074 * * * \\
(0.027)\end{array}$ & $\begin{array}{c}0.087 * * * \\
(0.027)\end{array}$ & $\begin{array}{c}0.079 * * * \\
(0.027)\end{array}$ & $\begin{array}{c}0.054 * * * \\
(0.017)\end{array}$ & $\begin{array}{c}0.051 * * * \\
(0.016)\end{array}$ & $\begin{array}{c}0.060 * * * \\
(0.017)\end{array}$ & $\begin{array}{c}0.058 * * * \\
(0.017)\end{array}$ \\
\hline Population & & $\begin{array}{c}-0.010^{* * *} \\
(0.002)\end{array}$ & & $\begin{array}{c}-0.007^{* * *} \\
(0.001)\end{array}$ & & $\begin{array}{c}-0.003 * * * \\
(0.001)\end{array}$ & & $\begin{array}{c}-0.002^{* * *} \\
(0.001)\end{array}$ \\
\hline Share of female & & $\begin{array}{l}0.385 * \\
(0.201)\end{array}$ & & $\begin{array}{c}0.269 \\
(0.177)\end{array}$ & & $\begin{array}{c}0.201 \\
(0.146)\end{array}$ & & $\begin{array}{l}-0.066 \\
(0.131)\end{array}$ \\
\hline Share of foreigners & & $\begin{array}{c}0.091 \\
(0.109)\end{array}$ & & $\begin{array}{c}0.065 \\
(0.063)\end{array}$ & & $\begin{array}{c}0.014 \\
(0.055)\end{array}$ & & $\begin{array}{l}-0.015 \\
(0.035)\end{array}$ \\
\hline Share of population $>75$ years & & $\begin{array}{l}-0.140 \\
(0.162)\end{array}$ & & $\begin{array}{c}-0.284 * * \\
(0.137)\end{array}$ & & $\begin{array}{l}-0.245 \\
(0.180)\end{array}$ & & $\begin{array}{c}-0.160 * * \\
(0.080)\end{array}$ \\
\hline Unemployed per 1,000 capita & & $\begin{array}{l}-0.121 \\
(0.189)\end{array}$ & & $\begin{array}{c}-0.277^{*} \\
(0.153)\end{array}$ & & $\begin{array}{c}-0.277 * * \\
(0.135)\end{array}$ & & $\begin{array}{c}-0.332 * * * \\
(0.103)\end{array}$ \\
\hline Tах revenue & & $\begin{array}{l}6.620 * \\
(3.424)\end{array}$ & & $\begin{array}{c}3.648 \\
(2.427)\end{array}$ & & $\begin{array}{c}1.651 \\
(2.528)\end{array}$ & & $\begin{array}{c}1.237 \\
(1.411)\end{array}$ \\
\hline Rainfall & & $\begin{array}{c}-2.322 * * \\
(0.952)\end{array}$ & & $\begin{array}{l}-1.560 * \\
(0.847)\end{array}$ & & $\begin{array}{c}-2.785 * * * \\
(0.836)\end{array}$ & & $\begin{array}{c}-2.545^{* * *} \\
(0.841)\end{array}$ \\
\hline National election & & & & $\begin{array}{c}6.132 * * * \\
(0.656)\end{array}$ & & & & $\begin{array}{c}-4.287 * * * \\
(0.887)\end{array}$ \\
\hline Election liberalization & & $\begin{array}{c}-7.151^{* * *} \\
(1.289)\end{array}$ & & $\begin{array}{c}-15.410^{* * *} \\
(0.681)\end{array}$ & & $\begin{array}{c}-4.699 * * * \\
(0.976)\end{array}$ & & $\begin{array}{c}-16.524 * * * \\
(0.512)\end{array}$ \\
\hline Constant & $\begin{array}{c}73.791^{* * *} \\
(0.246)\end{array}$ & $\begin{array}{c}76.204 * * * \\
(10.194)\end{array}$ & $\begin{array}{c}73.009 * * * \\
(0.334)\end{array}$ & $\begin{array}{c}79.855^{* * *} \\
(8.944)\end{array}$ & $\begin{array}{c}75.661 * * * \\
(0.723)\end{array}$ & $\begin{array}{c}79.442 * * * \\
(8.043)\end{array}$ & $\begin{array}{c}72.146 * * * \\
(0.274)\end{array}$ & $\begin{array}{c}101.545^{* * *} \\
(6.722)\end{array}$ \\
\hline Municipality fixed effects & Yes & Yes & Yes & Yes & Yes & Yes & Yes & Yes \\
\hline Time fixed effects & Yes & Yes & Yes & Yes & Yes & Yes & Yes & Yes \\
\hline Obs. & 332 & 332 & 747 & 747 & 684 & 684 & 1,539 & 1,539 \\
\hline Within R-squared & 0.756 & 0.782 & 0.799 & 0.809 & 0.785 & 0.800 & 0.803 & 0.808 \\
\hline \multicolumn{9}{|l|}{ Oster (2013) bound estimates } \\
\hline Identified $\beta$-set & \multicolumn{2}{|c|}{$[0.074,0.098]$} & \multicolumn{2}{|c|}{$[0.079,0.109]$} & \multicolumn{2}{|c|}{$[0.051,0.067]$} & \multicolumn{2}{|c|}{$[0.058,0.082]$} \\
\hline$\left|\delta^{0}\right|$ (Restricted: Muni. fixed eff.) & \multicolumn{2}{|c|}{3.034} & \multicolumn{2}{|c|}{2.643} & \multicolumn{2}{|c|}{3.212} & \multicolumn{2}{|c|}{2.340} \\
\hline$\left|\delta^{0}\right|$ (Restricted to: Time fixed eff.) & \multicolumn{2}{|c|}{10.086} & \multicolumn{2}{|c|}{6.610} & \multicolumn{2}{|c|}{27.853} & \multicolumn{2}{|c|}{132.976} \\
\hline
\end{tabular}

Notes: Voter turnout is the dependent variable. All estimations include municipality and time fixed effects. National election: dummy for all national elections. Election liberalization: dummy for all elections after 2007 (introduction of postal voting, decrease in legal voting age, see Table 1). Oster (2013) bound estimates: Relative impact of unobservables to observables needed to attribute the full treatment effect to unobservables $\left(\left|\delta^{0}\right|\right)$; squared brackets: identified $\beta$-set. Significance levels (standard errors clustered at the municipal level in brackets): *** 0.01, ** 0.05, * 0.10. 
TABLE 3. RoBustness TESTS

\begin{tabular}{|c|c|c|c|c|c|c|c|}
\hline \multirow{3}{*}{$\begin{array}{c}\text { Panel A } \\
\text { (Strict sample) }\end{array}$} & \multicolumn{7}{|c|}{ Dependent variable: Voter turnout } \\
\hline & Baseline & $\begin{array}{c}\text { Quadratic } \\
\text { specification }\end{array}$ & $\begin{array}{c}\text { Cross } \\
\text { Section }\end{array}$ & $\begin{array}{l}\text { One locality } \\
\text { only }\end{array}$ & $\begin{array}{c}\text { Postal votes } \\
\text { added }\end{array}$ & $\begin{array}{c}\text { Placebo } \\
\text { treatment }\end{array}$ & $\begin{array}{l}\text { Pre-reform } \\
\text { treatments }\end{array}$ \\
\hline & (1) & (2) & (3) & (4) & (5) & (6) & (7) \\
\hline \multirow[t]{2}{*}{ Treat $\times$ Reform } & $0.079 * * *$ & $0.298 * * *$ & $0.084^{* * *}$ & $0.114^{* *}$ & $0.067^{* *}$ & 0.005 & $0.070^{* *}$ \\
\hline & $(0.027)$ & $(0.110)$ & $(0.031)$ & $(0.048)$ & $(0.026)$ & $(0.025)$ & $(0.031)$ \\
\hline \multirow[t]{2}{*}{$(\text { Treat } \times \text { Reform })^{2}$} & & $-0.002^{* *}$ & & & & & \\
\hline & & $(0.001)$ & & & & & \\
\hline \multirow[t]{2}{*}{ Treat $\times 2016$} & & & & & & & -0.003 \\
\hline & & & & & & & $(0.027)$ \\
\hline \multirow[t]{2}{*}{ Treat $\times 2010$} & & & & & & & 0.023 \\
\hline & & & & & & & $(0.035)$ \\
\hline \multirow[t]{2}{*}{ Treat $\times 2008$} & & & & & & & -0.018 \\
\hline & & & & & & & $(0.030)$ \\
\hline \multirow[t]{2}{*}{ Treat $\times 2006$} & & & & & & & -0.002 \\
\hline & & & & & & & $(0.030)$ \\
\hline \multirow[t]{2}{*}{ Treat $\times 2005$} & & & & & & & 0.022 \\
\hline & & & & & & & $(0.030)$ \\
\hline \multirow[t]{2}{*}{ Treat $\times 2002$} & & & & & & & $-0.061 * *$ \\
\hline & & & & & & & $(0.029)$ \\
\hline \multirow[t]{2}{*}{ Treat $\times 2000$} & & & & & & & -0.060 \\
\hline & & & & & & & $(0.038)$ \\
\hline Full set of controls & Yes & Yes & Yes & Yes & Yes & Yes & Yes \\
\hline Municipality fixed effects & Yes & Yes & No & Yes & Yes & Yes & Yes \\
\hline Time fixed effects & Yes & Yes & Yes & Yes & Yes & Yes & Yes \\
\hline Obs. & 747 & 747 & 249 & 504 & 747 & 747 & 747 \\
\hline \multirow[t]{2}{*}{ Within R-squared } & 0.809 & 0.810 & 0.410 & 0.816 & 0.728 & 0.806 & 0.814 \\
\hline & & & $\overline{D e p}$ & variable: $\mathrm{Vot}$ & urnout & & \\
\hline $\begin{array}{c}\text { Panel B } \\
\text { (Full sample) }\end{array}$ & Baseline & $\begin{array}{c}\text { Quadratic } \\
\text { specification }\end{array}$ & $\begin{array}{l}\text { Cross } \\
\text { Section }\end{array}$ & $\begin{array}{c}\text { One locality } \\
\text { only }\end{array}$ & $\begin{array}{c}\text { Postal votes } \\
\text { added }\end{array}$ & $\begin{array}{l}\text { Placebo } \\
\text { treatment }\end{array}$ & $\begin{array}{l}\text { Pre-reform } \\
\text { treatments }\end{array}$ \\
\hline & (1) & (2) & (3) & (4) & (5) & (6) & (7) \\
\hline Treat $\times$ Reform & $0.058 * * *$ & $0.219 * * *$ & $0.067 * * *$ & $0.062 * *$ & $0.048 * * *$ & 0.018 & $0.048 * *$ \\
\hline & $(0.017)$ & $(0.074)$ & $(0.025)$ & $(0.029)$ & $(0.016)$ & $(0.017)$ & $(0.022)$ \\
\hline$(\text { Treat } \times \text { Reform })^{2}$ & & $-0.002^{* *}$ & & & & & \\
\hline & & $(0.001)$ & & & & & \\
\hline Treat $\times 2016$ & & & & & & & -0.020 \\
\hline & & & & & & & $(0.017)$ \\
\hline Treat $\times 2010$ & & & & & & & 0.017 \\
\hline & & & & & & & $(0.023)$ \\
\hline Treat $\times 2008$ & & & & & & & -0.019 \\
\hline & & & & & & & $(0.020)$ \\
\hline Treat $\times 2006$ & & & & & & & 0.001 \\
\hline & & & & & & & $(0.019)$ \\
\hline Treat $\times 2005$ & & & & & & & 0.003 \\
\hline & & & & & & & $(0.020)$ \\
\hline Treat $\times 2002$ & & & & & & & -0.028 \\
\hline & & & & & & & $(0.020)$ \\
\hline Treat $\times 2000$ & & & & & & & -0.030 \\
\hline & & & & & & & $(0.021)$ \\
\hline Full set of controls & Yes & Yes & Yes & Yes & Yes & Yes & Yes \\
\hline Municipality fixed effects & Yes & Yes & No & Yes & Yes & Yes & Yes \\
\hline Time fixed effects & Yes & Yes & Yes & Yes & Yes & Yes & Yes \\
\hline Obs. & 1,539 & 1,539 & 513 & 1,008 & 1,539 & 1,539 & 1,539 \\
\hline Within R-squared & 0.808 & 0.809 & 0.399 & 0.798 & 0.733 & 0.806 & 0.809 \\
\hline
\end{tabular}

Notes: Voter turnout is the dependent variable. All estimations except column (3) include a full set of controls (Table 2), municipality and time fixed effects. Cross Section: Last pre-reform and first post-reform election only; estimation includes a dummy Treat and a variable Reform and excludes municipality fixed effects. One locality only: Municipalities consisting of one locality only. Postal votes added: District-level voter turnout in postal voting added to municipal-level voter turnout. Placebo treatment: Assignment of the treatments by alphabetical order. Sub-periods: Interaction of relative increase in voter turnout with time fixed effects (reference category: interaction of treat and 2013). By definition, Treat $\times$ Reform $\equiv$ Treat $\times 2015$. Significance levels (robust standard errors clustered at the municipal level in brackets): *** 0.01, ** 0.05, * 0.10 . 
TABLE 4. EFFECTS BY TREATMENT INTENSITY

\begin{tabular}{|c|c|c|c|c|}
\hline & \multicolumn{4}{|c|}{ Dependent variable: Voter turnout } \\
\hline & \multicolumn{2}{|c|}{$\begin{array}{c}\text { Panel A } \\
\text { (Strict sample) }\end{array}$} & \multicolumn{2}{|c|}{$\begin{array}{c}\text { Panel B } \\
\text { (Full sample) }\end{array}$} \\
\hline & $\begin{array}{l}\text { High treatment } \\
\text { intensity }\end{array}$ & $\begin{array}{l}\text { Low treatment } \\
\text { intensity }\end{array}$ & $\begin{array}{l}\text { High treatment } \\
\text { intensity }\end{array}$ & $\begin{array}{l}\text { Low treatment } \\
\text { intensity }\end{array}$ \\
\hline & (1) & (2) & (3) & (4) \\
\hline \multirow[t]{2}{*}{ Treat $\times$ Reform } & 0.050 & 0.274 & $0.048^{* *}$ & -0.012 \\
\hline & $(0.035)$ & $(0.205)$ & $(0.020)$ & $(0.039)$ \\
\hline Full set of controls & Yes & Yes & Yes & Yes \\
\hline Municipality fixed effects & Yes & Yes & Yes & Yes \\
\hline Time fixed effects & Yes & Yes & Yes & Yes \\
\hline Obs. & 531 & 216 & 999 & 540 \\
\hline Within R-squared & 0.799 & 0.844 & 0.791 & 0.849 \\
\hline
\end{tabular}

Notes: Voter turnout is the dependent variable. All estimations include a full set of controls (Table 2), municipality and time fixed effects. High treatment intensity: Pre-reform opening hours of polling stations: $<7$ hours (state election 2010). Low treatment intensity: Pre-reform opening hours of polling stations: $\geq 7$ hours (state election 2010). Significance levels (standard errors clustered at the municipal level in brackets): *** 0.01 , ** $0.05, * 0.10$. 
TABLE 5. EXCLUDING OTHER CHANNELS

\begin{tabular}{|c|c|c|c|c|c|}
\hline \multirow{4}{*}{$\begin{array}{c}\text { Panel A } \\
\text { (Strict sample) }\end{array}$} & \multicolumn{5}{|c|}{ Dependent variable: Voter turnout } \\
\hline & \multirow{3}{*}{$\begin{array}{c}\text { Baseline } \\
(1)\end{array}$} & \multicolumn{4}{|c|}{ Other channel } \\
\hline & & \multirow{2}{*}{$\begin{array}{c}\text { Friday voting } \\
\text { (2) }\end{array}$} & \multirow{2}{*}{$\begin{array}{c}\begin{array}{c}\text { Second election } \\
\text { day }\end{array} \\
(3)\end{array}$} & \multicolumn{2}{|c|}{$\begin{array}{c}\text { Lack of } \\
\text { ballot boxes }\end{array}$} \\
\hline & & & & (4) & (5) \\
\hline Treat $\times$ Reform & $\begin{array}{c}0.079 * * * \\
(0.027)\end{array}$ & $\begin{array}{c}0.081^{* * * *} \\
(0.026)\end{array}$ & $\begin{array}{c}0.077 * * * \\
(0.028)\end{array}$ & $\begin{array}{l}0.084^{* *} \\
(0.038)\end{array}$ & $\begin{array}{c}0.101^{* * *} \\
(0.035)\end{array}$ \\
\hline Share of commuters $\times$ Reform & & $\begin{array}{c}0.015 \\
(0.054)\end{array}$ & & & \\
\hline Share of workforce $\times$ Reform & & & $\begin{array}{l}-0.013 \\
(0.064)\end{array}$ & & \\
\hline Share of voters without own ballot box $\times$ Reform & & & & $\begin{array}{l}-0.004 \\
(0.019)\end{array}$ & \\
\hline Distance to ballot box on sec. elec. day $\times$ Reform & & & & & $\begin{array}{l}-0.599 \\
(0.465)\end{array}$ \\
\hline Full set of controls & Yes & Yes & Yes & Yes & Yes \\
\hline Municipality fixed effects & Yes & Yes & Yes & Yes & Yes \\
\hline Time fixed effects & Yes & Yes & Yes & Yes & Yes \\
\hline Obs. & 747 & 747 & 747 & 747 & 747 \\
\hline \multirow[t]{5}{*}{ Within R-squared } & 0.809 & 0.809 & 0.809 & 0.809 & 0.810 \\
\hline & \multicolumn{5}{|c|}{ Dependent variable: Voter turnout } \\
\hline & & \multicolumn{4}{|c|}{ Other channel } \\
\hline & Baseline & Friday voting & $\begin{array}{c}\text { Second election } \\
\text { day }\end{array}$ & \multicolumn{2}{|c|}{$\begin{array}{c}\text { Lack of } \\
\text { ballot boxes }\end{array}$} \\
\hline & $(1)$ & (2) & (3) & (4) & $(5)$ \\
\hline Treat $\times$ Reform & $\begin{array}{c}0.058 * * * \\
(0.017)\end{array}$ & $\begin{array}{c}0.058 * * * \\
(0.018)\end{array}$ & $\begin{array}{c}0.052 * * * \\
(0.018)\end{array}$ & $\begin{array}{c}0.056 * * * \\
(0.021)\end{array}$ & $\begin{array}{c}0.068 * * * \\
(0.024)\end{array}$ \\
\hline Share of commuters $\times$ Reform & & $\begin{array}{c}0.001 \\
(0.049)\end{array}$ & & & \\
\hline Share of workforce $\times$ Reform & & & $\begin{array}{l}-0.047 \\
(0.051)\end{array}$ & & \\
\hline Share of voters without own ballot box $\times$ Reform & & & & $\begin{array}{c}0.002 \\
(0.012)\end{array}$ & \\
\hline Distance to ballot box on sec. elec. day $\times$ Reform & & & & & $\begin{array}{l}-0.364 \\
(0.390)\end{array}$ \\
\hline Full set of controls & Yes & Yes & Yes & Yes & Yes \\
\hline Municipality fixed effects & Yes & Yes & Yes & Yes & Yes \\
\hline Time fixed effects & Yes & Yes & Yes & Yes & Yes \\
\hline Obs. & 1,539 & 1,539 & 1,539 & 1,539 & 1,539 \\
\hline Within $R$-squared & 0.808 & 0.808 & 0.808 & 0.808 & 0.808 \\
\hline
\end{tabular}

Notes: Voter turnout is the dependent variable. All estimations include a full set of controls (Table 2), municipality and time fixed effects. Friday voting: Treat replaced by the ratio of commuters by electorate. Second election day: Treat replaced by the ratio of workforce by electorate. Lack of ballot boxes: Treat replaced by the share of electorate in localities without an own ballot box on the second election day. Significance levels (standard errors clustered at the municipal level in brackets): ***0.01, ** 0.05, *0.10. 
TABLE 6. EFFECT ON VOTE SHARES

\begin{tabular}{|c|c|c|c|c|c|c|c|c|c|c|}
\hline & \multicolumn{10}{|c|}{ Dependent variable: Vote share } \\
\hline & \multicolumn{5}{|c|}{$\begin{array}{c}\text { Panel A } \\
\text { (Strict sample) }\end{array}$} & \multicolumn{5}{|c|}{$\begin{array}{c}\text { Panel B } \\
\text { (Full sample) }\end{array}$} \\
\hline & SPÖ & ÖVP & $F P O ̈$ & Greens & Others & SPÖ & $\ddot{O V P}$ & $F P O ̈$ & Greens & Others \\
\hline & (1) & $(2)$ & (3) & (4) & (5) & (6) & (7) & (8) & (9) & $(10)$ \\
\hline \multicolumn{11}{|l|}{ State and national elections } \\
\hline \multirow[t]{2}{*}{ Treat $\times$ Reform } & 0.046 & $-0.119 * * *$ & $0.052 *$ & $0.027 * * *$ & -0.006 & $0.072 * * *$ & $-0.091 * * *$ & $0.038 * *$ & 0.003 & -0.023 \\
\hline & $(0.039)$ & $(0.026)$ & $(0.027)$ & $(0.010)$ & $(0.021)$ & $(0.020)$ & $(0.019)$ & $(0.017)$ & $(0.007)$ & $(0.017)$ \\
\hline Full set of controls & Yes & Yes & Yes & Yes & Yes & Yes & Yes & Yes & Yes & Yes \\
\hline Municipality fixed effects & Yes & Yes & Yes & Yes & Yes & Yes & Yes & Yes & Yes & Yes \\
\hline Time fixed effects & Yes & Yes & Yes & Yes & Yes & Yes & Yes & Yes & Yes & Yes \\
\hline Obs. & 664 & 664 & 664 & 664 & 664 & 1,368 & 1,368 & 1,368 & 1,368 & 1,368 \\
\hline Within R-squared & 0.667 & 0.671 & 0.770 & 0.390 & 0.830 & 0.653 & 0.695 & 0.753 & 0.350 & 0.764 \\
\hline \multicolumn{11}{|l|}{ State elections } \\
\hline \multirow[t]{2}{*}{ Treat $\times$ Reform } & $0.080 *$ & $-0.172 * * *$ & $0.069 * *$ & $0.036 * * *$ & -0.014 & $0.095 * * *$ & $-0.124 * * *$ & $0.048 * *$ & 0.006 & -0.025 \\
\hline & $(0.043)$ & $(0.030)$ & $(0.030)$ & $(0.011)$ & $(0.020)$ & $(0.022)$ & $(0.022)$ & $(0.020)$ & $(0.007)$ & $(0.017)$ \\
\hline Full set of controls & Yes & Yes & Yes & Yes & Yes & Yes & Yes & Yes & Yes & Yes \\
\hline Municipality fixed effects & Yes & Yes & Yes & Yes & Yes & Yes & Yes & Yes & Yes & Yes \\
\hline Time fixed effects & Yes & Yes & Yes & Yes & Yes & Yes & Yes & Yes & Yes & Yes \\
\hline Obs. & 332 & 332 & 332 & 332 & 332 & 684 & 684 & 684 & 684 & 684 \\
\hline Within R-squared & 0.599 & 0.429 & 0.650 & 0.444 & 0.716 & 0.590 & 0.468 & 0.650 & 0.409 & 0.599 \\
\hline
\end{tabular}

Notes: The vote share for the SPÖ, ÖVP, FPÖ, Greens, or all other parties is the dependent variable each. All estimations include a full set of controls (Table 2), municipality and time fixed effects. State and national elections only (no presidential election). Significance levels (standard errors clustered at the municipal level in brackets): $* * * 0.01, * * 0.05, * 0.10$. 


\section{Appendix}

FiguRE A.1. PRE-REFORM CHARACTERISTICS AND CHANGE IN OPENING HOURS (2010-2015)
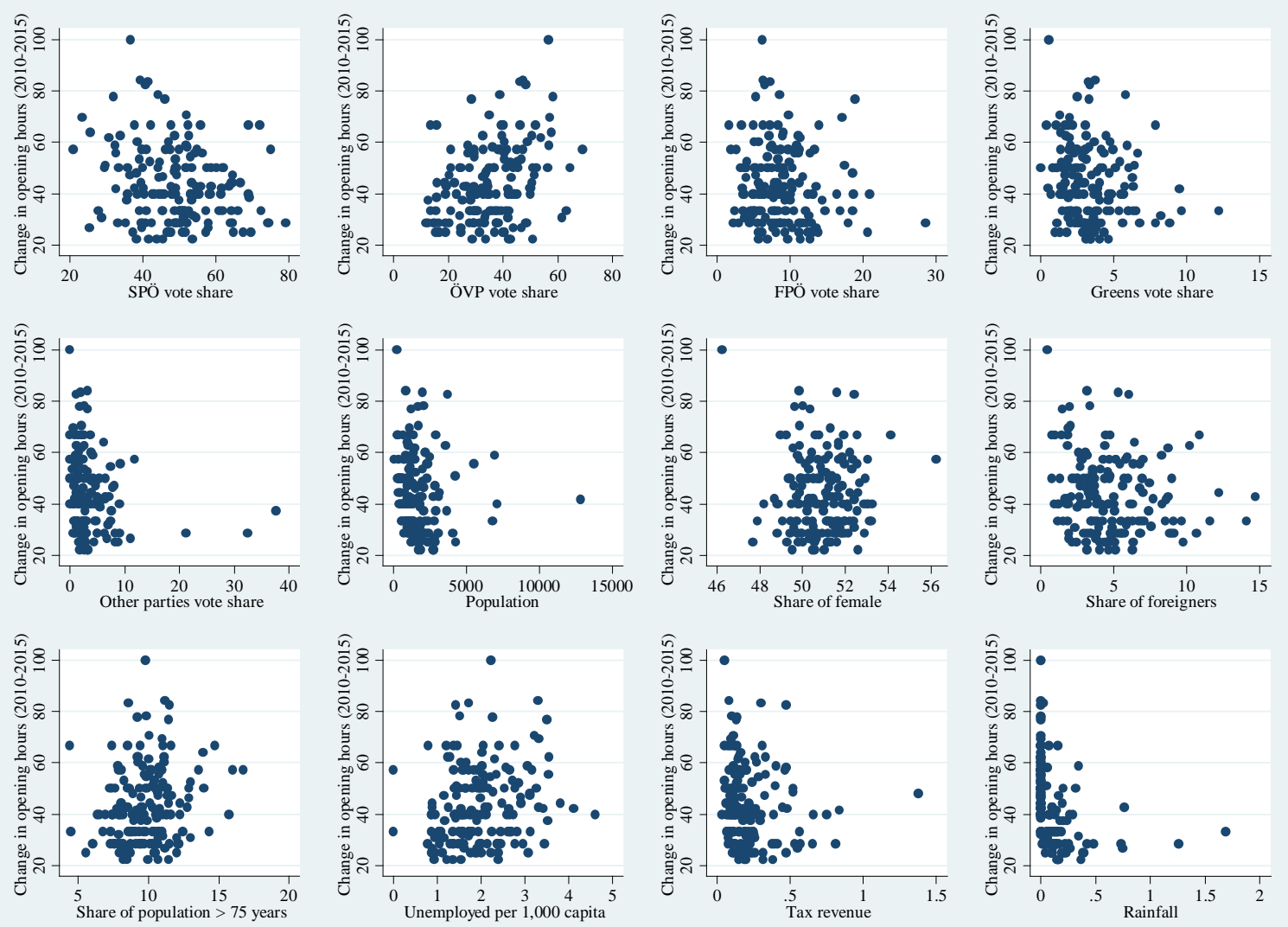

Notes: The figures plot pre-reform characteristics (2010) against the relative change in opening hours from 2010 to 2015 (municipal level). The correlation coefficients between treatment intensity and the individual variables are: -0.22 (SPÖ vote share), 0.35 (ÖVP vote share), -0.12 (FPÖ vote share), -0.16 (Greens vote share), -0.17 (other parties vote share), -0.11 (population), -0.02 (share of females), -0.17 (share of foreigners), 0.17 (share of population >75 years), 0.17 (unemployment per 1000 capita), 0.12 (tax revenue), -0.35 (rainfall). 
TABlE A.1. DATA SOURCES AND DEFINITIONS

\begin{tabular}{|c|c|c|}
\hline Variable & Source & Comments/Definition \\
\hline Voter turnout & $\begin{array}{l}\text { State government of Burgenland, } \\
\text { Federal government of Austria }\end{array}$ & $\begin{array}{l}\text { Without turnout from postal voting (added separately in } \\
\text { robustness tests, postal voting data unavailable for } \\
\text { 2015). Election dates (N: national election, S: state } \\
\text { election, P: Presidential election): 03.12.2000 (S), } \\
\text { 24.11.2002 (N), 09.10.2005 (S), 01.10.2006 (N), } \\
\text { 28.09.2008 (N), } 30.05 .2010(\mathrm{~S}), 29.09 .2013(\mathrm{~N}) \text {, } \\
\text { 22.05./31.05.2015 (S), 24.04.2016 (P). }\end{array}$ \\
\hline Opening hours of polling stations & District governments of Burgenland & - \\
\hline Population & Federal Statistical Office of Austria & 2000: Figures from 2001 census. \\
\hline Share of female & Federal Statistical Office of Austria & 2000: Figures from 2001 census. \\
\hline Share of foreigners & Federal Statistical Office of Austria & 2000: Figures from 2001 census. \\
\hline Share of population $>75$ years & Federal Statistical Office of Austria & 2000: Figures from 2001 census. \\
\hline Unemployed per 1,000 capita & Unemployment Agency of Austria & Last month/quarter before election. \\
\hline Tax revenue & Federal Statistical Office of Austria & $\begin{array}{l}\text { Total municipal tax revenue per capita. 2016: Figures } \\
\text { from } 2015 .\end{array}$ \\
\hline Rainfall & Hydrological Office of Burgenland & $\begin{array}{l}\text { Average rainfall in a municipality in milliliter (liter per } \\
\text { square meter) per opening hour. Technically, we } \\
\text { compute the average hourly rainfall during the } \\
\text { municipal-specific opening hours of polling stations on } \\
\text { election day. We use the three weather measuring points } \\
\text { in Burgenland nearest to the center of a municipality, } \\
\text { weighted by their inverse distance. }\end{array}$ \\
\hline Share of commuters & Federal Statistical Office of Austria & $\begin{array}{l}\text { 2015: Figures from 2013. Municipal workforce } \\
\text { commuting to other municipalities (Erwerbspendler) as } \\
\text { a share of total population. }\end{array}$ \\
\hline Share of workforce & Federal Statistical Office of Austria & $\begin{array}{l}\text { 2015: Figures from } 2013 \text {. Total municipal workforce as } \\
\text { a share of total population. }\end{array}$ \\
\hline Share of voters without own ballot box & Federal Statistical Office of Austria & $\begin{array}{l}\text { Share of municipal electorate living in localities without } \\
\text { an own ballot box at the second election day in } 2015\end{array}$ \\
\hline Party vote shares & $\begin{array}{l}\text { State government of Burgenland, } \\
\text { Federal government of Austria }\end{array}$ & $\begin{array}{l}\text { Without votes from postal voting. For election dates see } \\
\text { first row. }\end{array}$ \\
\hline
\end{tabular}

Notes: The table shows the data sources of this study. 
TABLE A.2. Robustness Tests For EFFECTS ON VOte SHARES

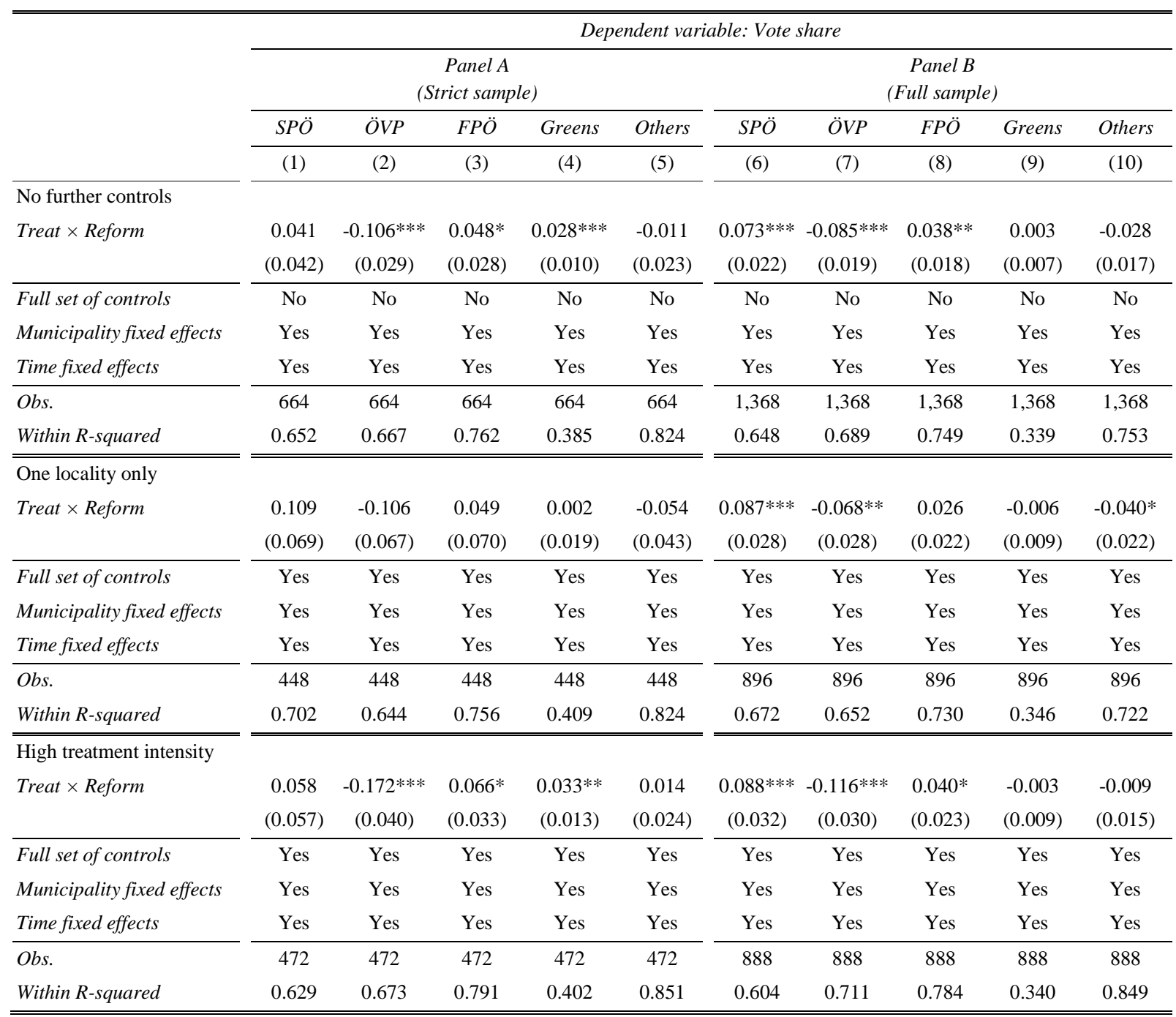

Notes: The vote share for the SPÖ, ÖVP, FPÖ, Greens, or all other parties is the dependent variable each. All estimations except the setting "No further controls" include a full set of controls (Table 2), municipality and time fixed effects. State and national elections only (no presidential election). Significance levels (standard errors clustered at the municipal level in brackets): ${ }^{* * *} 0.01, * * 0.05, * 0.10$. 